\title{
Cell therapy as a new approach on hepatic fibrosis of murine model of Schistosoma mansoni infection
}

\author{
Muslimah, N. ALsulami \\ Biology Department, Faculty of Science, University of Jeddah, Jeddah, Saudi Arabia \\ E-mail: mnal-sulami@uj.edu.sa \\ phone: +966554976745 . \\ Address: Jeddah, Saudi Arabia
}

\begin{abstract}
:
Schistosomiasis is an acute and chronic disease caused by blood flukes (trematode worms) of the genus Schistosoma. Schistosomiasis is disease that are prevalent in or unique to tropical and subtropical regions. Previous studies have shown that the role of bone marrow mesenchymal stem cells (BMSCs) therapy in improvement of hepatic fibrosis. Therefore, the current study was designed to assess the therapeutic role of BMSCs in murine schistosomiasis mansoni. BMSCs derived male mice were intraperitoneal injected into female mice that received $S$. mansoni cercariae through subcutaneous route. Mice were divided into four groups: negative control group (noninfected non treated); positive control group (infected non treated); BMSCs treated group; and untreated group. Liver histopathology and immunohistochemically were evaluated. BMSC intraperitoneal injection resulted in a significant reduction in liver collagen, granuloma size, and significant increase in OV-6 expression in the Schistosomiasis treated mice group. There was overall improvement of the pathological changes of the liver. The findings support that BMSCs has a regenerative potential in the histopathology and function of the liver tissue by decreasing liver fibrosis.
\end{abstract}

Keywords: BMSCs, histopathology, Schistosoma mansoni, OV-6 


\section{Introduction}

Schistosomiasis is caused by a trematode of Schistosomiasis and it is considered as a chronic debilitating disease. Schistosomiasis is considered the second disease after malaria infection in terms of its importance to public health, economic, and social effect. Estimates show that at least 207 million people infected all over the world, while 779 million people are still at risk (Santiago et al., 2014).

World Health Organization (WHO) proved that more than 200,000 deaths due to schistosomiasis each year in sub-Saharan Africa (WHO 2012). The most common cause of schistosomiasis in human is infection by Schistosoma mansoni. The disease is caused due to formation of a granulomatous reaction around the eggs of the parasite in the liver tissues (Gryseels et al., 2006).

Cirrhosis occurs as a result of chronic liver disease with various causes, including schistosomiasis which considered the most common cause of cirrhosis. One of the experimental models of liver fibrosis was infection with $S$. mansoni. It is used to illustrate the mechanism of the fibrosis (El-Mahdi et al., 2014).

Since 1970, the drug of choice is praziquantel (PZQ), which has proven effective in the prevention of some species of schistosomes, such as $S$. mansoni, $S$. hematobium, and $S$. japonicum and reduction of worm burden in infected patients. It is a safe oral drug that reduces the prevalence of schistosomiasis (Eissa et al., 2011). Therefore, the targeted and collective drug management program is currently heavily dependent on this drug to control morbidity induced by schistosomiasis (Inobaya et al., 2014).

With the choice of only one drug for treatment and the development of parasite resistance, the current situation is serious. Therefore, there is a real need to discover a new drug to mitigate the damages caused by liver fibrosis which induced by schistosomiasis (Fikry et al., 2016).

Previous studies reported that stem cells have a therapeutic role in tissue regeneration and require minor incursion procedures. They have used it lately because they have the capability of self-renewal and multilineage differentiation, which ably to diseases affecting human (Salama et al., 2010). It has been reported that transplanted bone marrow mesenchymal stem cells (BMSCs) lead to liver cell 
regeneration and perform a significant influence on liver structure and function (Aziz et al., 2012).

So, the destination of the current study was to assess the therapeutic role of BMSCs in the murine model of schistosomiasis mansoni.

\section{Materials and Methods:}

\section{Materials:}

- Reagents for cell culturing were purchased from Lonza Company, Swiss. They included:

- Dulbecco's modified Eagles medium (DMEM) contained 4.5g/L glucose and L-glutamine (Catalog NO.: 12-604Q).

- Fetal bovine serum (FBS) (Catalog NO.: 77227).

- Phosphate buffer saline (PBS): without $\mathrm{Ca}^{+2}$ and $\mathrm{Mg}$ sterile filtered for cell culture (catalog NO.: BEBP17-516Q).

- Penicillin streptomycin mixture in $100 \mathrm{mLs}$ bottles (Catalog NO.: 17602E).

- Trypsin-EDTA (Catalog NO.: 17-161E).

- Wizard Genomic DNA purification kit (Promega, Madison, WI, USA) (Catalog NO.: A1120).

- SRY gene Primer sequences: (forward 5' CATCGAAGGGTTAAAGTGCCA3', reverse 5'-ATAGTGTGTAG-GTTGTTGTCC-3') published sequences (Lee et al., (2010) (UniGene Rn.107239).

- Immune-histochemical staining for OV-6 using monoclonal anti-mouse OV-6 anti-human antibody. It was purchased from Life Technologies Corporation and R\&D Systems (Catalog NO.: FAB2020G).

\section{Experimental design}

In the current study, forty female BALB/c mice (aged 4 weeks, weighing 30- $40 \mathrm{~g}$ ) were used and housed at Theodor Bilharz Research Institute (TBRI), Egypt. The experiment was proceeded in according to applicable guidelines in TBRI's Animal Research Committee for testing animals. Animals were divided into four groups (10 mice/group) in this study.

Group I: negative control group; healthy uninfected mice injected intraperitoneal with phosphate buffer saline (PBS) and sacrificed after twelve weeks. 
Group II: positive control group; mice subcutaneously infected with 90 cercariae of S. mansoni and sacrificed after eight weeks. Cercariae were gained from infected Biomphalaria alexandrina snails at the TBRI.

Group III: mice were infected as group II and on the 8th week they were infused via intraperitoneal injection by BMSCs $\left(2 \times 10^{6}\right.$ cells/mouse) which derived from male mice then sacrificed after four weeks (Aziz et al., 2012).

Group IV: mice were infected as group II and left without treatment then sacrificed after twelve weeks. The infection was confirmed by examination of stool for the presence of $S$. mansoni eggs after 7 weeks from infection.

\section{Isolation and culture of BMSCs:}

In the current study, 6-weeks male BALB/c mice was used as a donor of BMSCs. The tibiae and femurs were flushed using complete media which formed of DMEM supplemented with 10\% FBS. Bone marrow cells resuspended for 2-3 days in complete media and incubated at $37^{\circ} \mathrm{C}$ in $5 \%$ humidified $\mathrm{CO}_{2}$. When colonies become confluence, cultures were washed with PBS. Then the cultures were trypsinized with trypsin EDTA for five minutes at $37^{\circ} \mathrm{C}$. Then centrifuged the suspension, viable and nonviable cells were counted using hemocytometer. The resulting cultures were considered the first-passage cultures (Abdel-Aziz et al., 2011). After the third passage the BMSCs were used for intraperitoneal injection in treated group.

\section{Determination of male derived BMSCs in the treated group by polymerase chain reaction $(\mathbf{P C R})$ :}

The presence or absence of the sex determination region on the $\mathrm{Y}$ chromosome male (sry) gene in recipient female mice was assessed by PCR. It was determined by Genomic DNA prepared from the tissue homogenate of liver tissue from mice in each group. The PCR were as follows: incubation at $94^{\circ} \mathrm{C}$ for $4 \mathrm{~min} ; 35$ cycles at $94^{\circ} \mathrm{C}$ for $50 \mathrm{~s}, 60^{\circ} \mathrm{C}$ for $30 \mathrm{~s}$ for optimal annealing, and $72^{\circ} \mathrm{C}$ for $1 \mathrm{~min}$ for extension; $72^{\circ} \mathrm{C}$ for $10 \mathrm{~min}$. PCR products were electrophoresed using $2 \%$ agarose gel electrophoresis and stained with ethidium bromide. Y chromosomes marker was expressed as trans-illuminated line of the amplified product appeared at 104 bp (Hong et al., 2013).

\section{Histopathology study:}


After proper fixation of liver specimens using $10 \%$ neutral buffered formalin the specimens were dehydrated, cleared in xylol, impregnated and then embedded in paraffin wax. Five microns sections were cut and mounted on glass slides. The consecutive slides were stained with the following stains:

Hematoxylin and eosin $(\mathrm{H} \& \mathrm{E})$ for examination of histopathological changes in the liver (Bancroft et al., 2013). Mallory stain to evaluate collagen content of the liver specimens (Bancroft et al., 2013). Immune-histochemical staining for OV-6 to evaluate the effect of transplanted BMSCs in the liver tissue (Hegab et al., 2018).

\section{Scanning electron microscope examination (SEM):}

SEM was used to analyze the ultrastructural of the adult male and female $S$. mansoni worms. After eight weeks, adult worms were recovered from both the hepatic portal system and the mesenteric veins. Adult male and female worms of Schistosoma mansoni samples that served as controls were washed from blood using PBS, fixed in a $10 \%$ glutaraldehyde and processed for examination using SEM (JEOL- JSM - 5500 LV) at the Regional Center of Mycology and Biotechnology, El Azhar University, Cairo, Egypt (Eissa et al., (2011); Kamel \& Bayomy, (2017)).

\section{Morphometric measurements}

The following parameters were measured using the image analyzer computer system (Leica Imaging System Ltd., Cambridge, U.K.). For each parameter at random selection of ten fields/ section in ten sections for every mouse in each group at magnification $\mathrm{x} 400$ in a standard frame of $24790 \mu^{2}$. The following parameters were measured: Area percentage of collagen fibers, the circumference of granulomatous lesion, and the mean number of OV-6 positive brown cells.

\section{Statistical analysis}

Analysis of data was performed using one way-ANOVA and post hoc using SPSS 21 computer Software. The results were expressed as Mean \pm standard Deviation (SD). $\mathrm{P}<0.05$ was considered statistically significant.

\section{Results}

\section{Scanning electron microscope examination:}


The adult male $S$. mansoni worm as visualized by SEM showed anterior region with the oral and ventral suckers. The body increases in width directly behind the ventral sucker and folds ventrally to form the gynaecophoric canal with numerous tubercles distributed along the body (Fig. 1A). The oval oral sucker showed three regions: a large anterior part and posterior part, both covered with sharp spines of variable size and at the bottom, the oral cavity (Fig. 1B). Ventral sucker bigger and more prominent than the oral sucker. Spines did not present in both surfaces (Fig. 1C). On the dorsal surface of male worm tubercles and tegumental ridges with several spines were seen (Figs. 1D, E). Adult female worms showed the oral, ventral suckers, the sensory papillae and the integrity of the tegument with no abnormality observed (Figs. 2A-D).

In the present study, the therapeutic potential of BMSCs on hepatic morbidity caused by Schistosoma mansoni was examined by culturing the undifferentiated BMSCs obtained from the femur and the tibia of male Balb/C mice with subsequent injection in the infected Balb/C female mice.

\section{Detection of male (Y chromosome) using PCR in the livers of female mice}

Homing of injected BMSCs in the diseased liver was examined by PCR. PCR was done to detect the Sry gene (Y chromosome marker) in the mice groups which were injected with BMSCs. Therefore, the corresponding 104 bp band was detected only in test group III using Sry gene specific detection primers (Fig. 3).

Histopathological and morphometric, immunohistochemical and laboratory examinations were done to assess the effect of BMSCs injection on liver morbidity of the infected mice with Schistosoma mansoni (group III) to be compared with the group II and IV.

\section{Haematoxylin and eosin liver sections:}

The control group showed normal histological appearance of the classic hepatic lobule. Hepatocytes were noticed radiating from the central vein and separated by blood sinusoids. The hepatocytes appeared to be polyhedral acidophilic cells with a central rounded vesicular nucleus while few of them were binucleated. The portal tract at the corners of the hepatic lobule consisted of a branch of hepatic artery, portal vein and a bile duct (Fig. 4A-B). H \& E stained sections of group III exhibited marked regenerative changes (Fig. 6A-D) compared to the infected non 
treated group II (Fig. 5A-C) and group IV (untreated group) (Fig7 A-D). These changes were demonstrated by reducing the infiltration of inflammatory cells, resolved pseudo-lobules and marked appearance of newly formed hepatocytes at the vicinity of the granuloma with a rounded dark nucleus.

Morphometric analysis of granuloma sizes of H\&E liver sections of Schistosomainfected female mice of studied groups was assessed as shown in Table $1 \&$ fig. 8 . There was a significant difference in mean area of the circumference of the granuloma size of group II, III and IV. There was a significant decrease in granuloma size of animal group III (treated with BMSCs) as compared to the group II (Schistosoma alone) and those mice of other groups IV (Untreated group). There was a significant increase was seen in animals of groups IV compared to groups II and III.

\section{Mallory stain for liver fibrosis:}

Examination of Mallory stained slides showed few collagen fibers around central veins. Group II (Schistosoma group) showed multiple large granuloma with apparent increase of fibrosis around portal vein with impacted adult worm inside it. Group III showed significant reduction in the size of the granuloma and in area percentage of fibrosis. Group IV (Untreated group) showed multiple large schistosomal granuloma with apparent increase of fibrosis around portal vein and sparing only few areas of hepatic tissue (Fig 9 A-E). Group II (Schistosoma group) showed large schistosomal granuloma with marked inflammatory cells around Schistosoma egg. Group III showed granuloma with well-organized fibrous tissue, calcified Schistosoma egg and sparing most of the hepatic tissue. Group IV (Untreated group) showed large schistosomal granuloma with increased degree of fibrosis around Schistosoma egg (Fig 10 A-C). The histological results confirmed by statistical results of the area percentage of collagen fibers staining by Mallory stain. There was significant reduction in both group II and group IV compared to the negative control animals (group I). There was also significant decrease in area percentage of collagen fibers in group III compared to those mice of groups II and IV (Table 1 and Fig. 11).

\section{Immuno-histochemical detection of positive brownish OV-6 cells:}


Positive OV-6 cells in liver sections of negative control group, $S$. mansoni infected group (positive control group), group III (treated with BMSCs), and group IV (untreated group) were detected immunohistochemically. It is an indicator for the new formed hepatocytes differentiate from BMSCs. Negative control group exhibited no brown-colored positive OV-6 in liver cells. In the treated group with BMSCs, brown-colored liver cells appeared between mouse liver cells and around granulomas either individually or in groups. Group II (positive control group) and group IV (untreated group) showed few positive OV-6 in between liver cells and around the granuloma (Figs. 11A-E). The histopathological results of the current study were confirmed by statistical results. There was a significant difference in number of OV-6 positive cells in the different groups. They reached their highest peaks in treated mice with BMSCs (group III) as compared to the negative control mice and those mice of other groups II (positive control) and IV (untreated). Nonsignificant difference in OV-6 positive cells was seen in mice of groups II as compared to that seen in the group IV (Table 1 and Fig.13).

\section{Discussion:}

Schistosomiasis is a chronic disease that is widespread all over the world. Schistosomiasis is endemic in 76 countries distributed all over the world especially in Africa and Asia (Mata-Santos et al., 2014). SEM plays a significant role in clarifying the detailed of the tegument of S. mansoni (El-Shabasy et al., (2015); Kamel et al., (2017)). SEM have been used by various researchers to explain how anti-schistosomal drugs act on the adult worms (de Oliveira et al., (2012); ElShabasy et al., (2015)). The tegument is main interface between the parasite and the host (El-Shabasy et al. 2015). The thick tegument acts as an important drug target because the surface membrane function and the integrity of the tegument are essential for survival of the worm and its proliferation. These structures play vital roles in the immune evasion and nutrient absorption in the host (Bertao et al., 2012). In the present study, the male worms appeared with numerous tubercles with typical spines, oral and ventral suckers and the gynecophoral canal. Female worms were observed with parallel fissures and tegument spines. These findings are similar to findings observed by Bertao et al., (2012) and Shabasy et al., (2015) in their in vivo study. 
The richest source of stem cells is the bone marrow (BM). BM derived stem cells (BM-DSCs) include mesenchymal stem cells (MSCs) and haemopoietic stem cells (HSCs). Enhanced understanding of these cells may help to develop novel therapies for regeneration of the diseased liver (Puglisi et al., (2011); De Miguel et al., (2019)). Wu et al., (2007) added that an important reason for using the BMSCs therapy is their ability to home to injured tissues after administration. Another reason for using BMSC is their ability to differentiate into different types of tissues. When Kinnaird et al., (2004) cultured BMSCs, they were able to differentiate into the vascular components of the vascular bed as they enhanced the proliferation of endothelial cells.

Different authors reported the in-vitro differentiate of MSCs to hepatocytes (Lee et al., (2004), Cho et al., (2009); Feng et al., (2011)) and in-vivo (Aurich et al., (2009); Hu \& Li et al., (2015)). Elkhafif et al., (2010) transplanted BMSCs derived from male mice via intrahepatic route into infected female mice and reported new hepatocyte formation with reduction of granuloma size and fibrosis. Consequently, bone marrow represents the first source of MSCs because they can be easily obtained after aspiration from the sternum or the iliac crest of the human volunteer donors after informed consent (Tondreau et al., 2004).

In the current study, liver infection was induced by subcutaneous infection of immuno-competent Balb/C mice with 90 cercariae of S. mansoni. This technique was also performed by other authors as Gryseels et al. (2006); Elkhafif et al. (2010); Hammam et al., (2016), who reported that inflammatory granulomas were formed inside livers of infected mice. Gryseels et al. (2006) described the acute liver granuloma on infected mouse (6-10weeks) post infection that appeared with different inflammatory cells, mainly eosinophils, lymphocytes, and macrophages. They also describe the chronic liver granuloma (16-20 weeks) post infection around the remains of the Schistosoma egg with dominant fibrous tissue.

In the present study, the regenerative capacity of the BMSCs was tested on murine model of S. mansoni infection. Intraperitoneal injection of BMSCs in S. mansoni infected mice lead to a significant reduction in the granuloma circumference and fibrotic areas with in-situ injection being the recommended route. This indicates that the inflammatory reaction and early fibrosis couldn't hinder MSCs from reaching the injured liver (Zhu et al., 2013). Moreover, Oliveria et al. (2008) 
mentioned significant decrease of liver fibrosis after stem cell therapy that was occurred due to both intralobular and intravenous transplantation of stem cells. It was found that intravenous transplantation was more effective than other routs of administration such as intrasplenic transplantation, intraperitoneal, and intrahepatic routes (Zhao et al., 2012). In addition, Xiang et al., (2005) mentioned that the homing of BMSCs to the liver due to liver injury but not due to the site of injection of BMSCs.

In the current work, the injected BMSCs have been homed within the injured tissue irrespective of the route of administration. This was demonstrated by detecting Y chromosome of male BMSCs in liver tissue of group III by PCR. Previous researchers mentioned the appearance of injected BMSCs in injured liver (Zhao et al., (2005); Aziz et al., (2007); Elkafif et al., (2010); El-Mahdi et al., (2014); Anan et al., (2016); Fikry et al., (2016)).

Different studies reported the regressive effect of BMSCs on liver fibrosis (Zhao et al., 2012). The mechanisms of the antifibrotic properties of BMSCs have been extensively studied; including inhibition of deposition of collagen fibers (Mohamadnejad et al., 2007 and Horton et al., 2013). Some authors reported increased levels of matrix metalloproteinase which may directly degrade the extracellular matrix and lead to apoptosis of hepatic stellate cell (HSCs) which is the cells responsible for fibrosis and collagen production in the liver tissue (Zhao et al., 2005). Recently, Ahmed et al., (2014) have reported that BMSCs were able to attenuate cirrhosis by a directly suppressing the activation of HSC, in an animal model of liver fibrosis induced by carbon-tetrachloride.

To confirm the regenerative findings in form of newly formed hepatocytes seen in $\mathrm{H} \& \mathrm{E}$ liver sections of treated BMSCs injected groups in the present work, immunohistochemical examination of OV-6 cells was done. It revealed the presence of newly formed hepatocytes in between the inflammatory cells at the vicinity of granuloma and also at the peripheral areas. They displayed a significant increase of positive cytoplasmic reaction of OV-6 cells. Oliveira et al. (2008) stated that increased 3-4 folds of oval cells were found in liver sections of mice treated with BMSCs which meant new hepatocytes formation. Similar findings were recorded by Elkhafif et al., (2010) who mentioned that the origin of the newly formed hepatocytes could be the injected BMSCs or from the liver itself 
(regenerated hepatocytes). Alison et al., (2009) reported that the improvements could be due to the secretion of growth factors by BMSCs, rather than to their differentiation into liver cells.

The present work showed high regenerative capacity of BMSCs as evidenced by the newly formed hepatocytes, the reduction of the inflammatory cells as well as the antifibrotic effect which were reflected on the granuloma size, the collagen fibers, OV-6 positive cells. This is also noticed by Hegab et al., (2018). Moreover, El-Mahdi et al., (2014) stated BMSCs could differentiate into liver cells which lead to improvement of the remaining liver cells function after severe hepatic injury. Also, Oval cells could be differentiated into hepatocytes, cells of bile duct, and promote hepatic regeneration (Wang et al., (2003); Fausto and Campbell, (2003)).

In conclusion, injection of BMSCs in $\mathrm{S}$. mansoni-infected mice resulted in decrease granulomas' size, regression of liver fibrosis and contributes to the generation of new hepatocytes. These findings reinforce the trial of BMSCs in patients with chronic and immunological liver diseases including schistosomiasis.

\section{References:}

1) Abdel aziz, M. T., El Asmar, M. F., Atta, H. M., Mahfouz, S., Fouad, H. H., Roshdy, N. K., ... Taha, F. M. (2011). Efficacy of mesenchymal stem cells in suppression of hepatocarcinorigenesis in rats: possible role of Wnt signaling. Journal of experimental \& clinical cancer research: $C R, 30(1), 49$. doi:10.1186/1756-9966-30-49

2) Ahmed, S. K., Mohammed, S. A., Khalaf, G., \& Fikry, H. (2014). Role of Bone Marrow Mesenchymal Stem Cells in the Treatment of CCL4 Induced Liver Fibrosis in Albino Rats: A Histological and Immunohistochemical Study. International journal of stem cells, 7(2), 87-97. doi:10.15283/ijsc.2014.7.2.87

3) Alison M, Islam S and Lim S (2009): Stem cells in liver regeneration, fibrosis and cancer: the good, the bad and the ugly. J Pathol: 217: 282-298.

4) Anan, H. H., Zidan, R. A., Shaheen, M. A., \& Abd-El Fattah, E. A. (2016). Therapeutic efficacy of bone marrow derived mesenchymal stromal cells versus losartan on adriamycin-induced renal cortical injury in adult albino rats. Cytotherapy, 18(8), 970-984. 
5) Aurich, H., Sgodda, M., Kaltwaßer, P., Vetter, M., Weise, A., Liehr, T., ... \& Christ, B. (2009). Hepatocyte differentiation of mesenchymal stem cells from human adipose tissue in vitro promotes hepatic integration in vivo. Gut, 58(4), 570-581.

6) Aziz, M. A., Atta, H. M., Mahfouz, S., Fouad, H. H., Roshdy, N. K., Ahmed, H. H., ... \& Hasan, N. M. (2007). Therapeutic potential of bone marrow-derived mesenchymal stem cells on experimental liver fibrosis. Clinical biochemistry, 40(12), 893-899.

7) Aziz, M. A., Atta, H. M., Roshdy, N. K., Rashed, L. A., Sabry, D., Hassouna, A. A., ... \& Chowdhury, J. R. (2012). Amelioration of murine Schistosoma mansoni induced liver fibrosis by mesenchymal stem cells. Journal of stem cells \& regenerative medicine, 8(1), 28.

8) Bancroft J, Layton C, Suvarna S., (2013). Bancroft's Theory and Practice of Histological Techniques. 7th ed. Elsevier Churchill Livingstone: London, United Kingdom 386-535.

9) Bertão HG, da Silva RA, Padilha RJ, de Azevedo Albuquerque MC, RádisBaptista G. (2012). Ultrastructural analysis of miltefosine-induced surface membrane damage in adult Schistosoma mansoni BH strain worms. Parasitol. Res. 110:2465-2473. http://dx.doi.org/10.1007/s00436 -011-2786-5.

10) Cho, K. A., Ju, S. Y., Cho, S. J., Jung, Y. J., Woo, S. Y., Seoh, J. Y., ... \& Ryu, K. H. (2009). Mesenchymal stem cells showed the highest potential for the regeneration of injured liver tissue compared with other subpopulations of the bone marrow. Cell Biology International, 33(7), 772-777.

11) De Miguel, M. P., Prieto, I., Moratilla, A., Arias, J., \& Aller, M. A. (2019). Mesenchymal Stem Cells for Liver Regeneration in Liver Failure: From Experimental Models to Clinical Trials. Stem cells international, 2019, 3945672. doi:10.1155/2019/3945672

12) De Oliveira, R. N., Rehder, V. L. G., Oliveira, A. S. S., Júnior, Í. M., de Carvalho, J. E., de Ruiz, A. L. T. G., ... \& Allegretti, S. M. (2012). Schistosoma mansoni: in vitro schistosomicidal activity of essential oil of Baccharis trimera (less) DC. Experimental parasitology, 132(2), 135-143.

13) Eissa, M. M., El Bardicy, S., \& Tadros, M. (2011). Bioactivity of miltefosine against aquatic stages of Schistosoma mansoni, Schistosoma haematobium and their snail hosts, supported by scanning electron microscopy. Parasites \& vectors, 4, 73. doi:10.1186/1756-3305-4-73 
14) Elkhafif, N., Voss, B., Hammam, O., Yehia, H., Mansy, S., Akl, M., ... \& El Fandy, G. (2010). Homing of transplanted bone marrow cells in livers of Schistosoma mansoni-infected mice. Apmis, 118(4), 277-287.

15) El-Mahdi, M. M., Mansour, W. A., Hammam, O., Mehana, N. A., \& Hussein, T. M. (2014). Ameliorative effect of bone marrow-derived stem cells on injured liver of mice infected with Schistosoma mansoni. The Korean journal of parasitology, 52(2), 151-162. doi:10.3347/kjp.2014.52.2.151

16) El-Shabasy, E. A., Reda, E. S., Abdeen, S. H., Said, A. E., \& Ouhtit, A. (2015). Transmission electron microscopic observations on ultrastructural alterations in Schistosoma mansoni adult worms recovered from C57BL/6 mice treated with radiation-attenuated vaccine and/or praziquantel in addition to passive immunization with normal and vaccinated rabbit sera against infection. Parasitology research, 114(4), 1563-1580.

17) Fausto N. and Campbell JS. (2003) The role of hepatocytes and oval cells in liver regeneration and repopulation. Mech Dev 120:117-130

18) Feng, J., Mantesso, A., De Bari, C., Nishiyama, A., \& Sharpe, P. T. (2011). Dual origin of mesenchymal stem cells contributing to organ growth and repair. Proceedings of the National Academy of Sciences, 108(16), 65036508.

19) Fikry, H., Gawad, S. A., \& Baher, W. (2016). Therapeutic Potential of Bone Marrow-Derived Mesenchymal Stem Cells on Experimental Liver Injury Induced by Schistosoma mansoni: A Histological Study. International journal of stem cells, 9(1), 96-106. doi:10.15283/ijsc.2016.9.1.96

20) Gryseels, B., Polman, K., Clerinx, J., \& Kestens, L. (2006). Human schistosomiasis. The Lancet, 368(9541), 1106-1118. 10.1016/S01406736(06)69440-3

21) Hammam, O. A., Elkhafif, N., Attia, Y. M., Mansour, M. T., Elmazar, M. M., Abdelsalam, R. M., ... El-Khatib, A. S. (2016). Wharton's jellyderived mesenchymal stem cells combined with praziquantel as a potential therapy for Schistosoma mansoni-induced liver fibrosis. Scientific reports, 6, 21005. doi:10.1038/srep21005

22) Hegab, M. H., Abd-Allah, S. H., Badawey, M. S., Saleh, A. A., Metwally, A. S., Fathy, G. M., ... \& El-Magd, M. A. (2018). Therapeutic potential effect of bone marrow-derived mesenchymal stem cells on chronic liver disease in murine Schistosomiasis Mansoni. Journal of parasitic diseases, 42(2), 277-286. 
23) Hong, K. U., Li, Q. H., Guo, Y., Patton, N. S., Moktar, A., Bhatnagar, A., \& Bolli, R. (2013). A highly sensitive and accurate method to quantify absolute numbers of c-kit+ cardiac stem cells following transplantation in mice. Basic research in cardiology, 108(3), 346. doi:10.1007/s00395-0130346-0

24) Horton, J. A., Hudak, K. E., Chung, E. J., White, A. O., Scroggins, B. T., Burkeen, J. F., \& Citrin, D. E. (2013). Mesenchymal stem cells inhibit cutaneous radiation-induced fibrosis by suppressing chronic inflammation. Stem cells, 31(10), 2231-2241.

25) Hu, C., \& Li, L. (2015). In vitro and in vivo hepatic differentiation of adult somatic stem cells and extraembryonic stem cells for treating end stage liver diseases. Stem cells international, 2015.

26) Inobaya, M. T., Olveda, R. M., Chau, T. N., Olveda, D. U., \& Ross, A. G. (2014). Prevention and control of schistosomiasis: a current perspective. Research and reports in tropical medicine, 2014(5), 65-75. doi:10.2147/RRTM.S44274

27) Kamel, R. O. A., \& Bayaumy, F. E. Z. A. (2017). Ultrastructural alterations in Schistosoma mansoni juvenile and adult male worms after in vitro incubation with primaquine. Memórias do Instituto Oswaldo Cruz, (AHEAD), $0-0$.

28) Kinnaird, T., Stabile, E., Burnett, M. S., Shou, M., Lee, C. W., Barr, S., ... \& Epstein, S. E. (2004). Local delivery of marrow-derived stromal cells augments collateral perfusion through paracrine mechanisms. Circulation, 109(12), 1543-1549.

29) Lee, R. H., Kim, B., Choi, I., Kim, H., Choi, H. S., Suh, K., ... \& Jung, J. S. (2004). Characterization and expression analysis of mesenchymal stem cells from human bone marrow and adipose tissue. Cellular physiology and biochemistry, 14(4-6), 311-324.

30) Lee, S. R., Lee, S. H., Moon, J. Y., Park, J. Y., Lee, D., Lim, S. J., ... \& Ihm, C. G. (2010). Repeated administration of bone marrow-derived mesenchymal stem cells improved the protective effects on a remnant kidney model. Renal failure, 32(7), 840-848.

31) Mata-Santos, H. A., Dutra, F. F., Rocha, C. C., Lino, F. G., Xavier, F. R., Chinalia, L. A., ... \& dos Santos Pyrrho, A. (2014). Silymarin reduces 
profibrogenic cytokines and reverses hepatic fibrosis in chronic murine schistosomiasis. Antimicrobial agents and chemotherapy, 58(4), 2076-2083.

32) Mohamadnejad, M., Alimoghaddam, K., Mohyeddin-Bonab, M., Bagheri, M., Bashtar, M., Ghanaati, H., ... \& Malekzadeh, R. (2007). Phase 1 trial of autologous bone marrow mesenchymal stem cell transplantation in patients with decompensated liver cirrhosis. Arch Iran Med, 10(4), 459-466.

33) Oliveira AS, Souza FSB, Ferreira CAG, Barreto SE et al (2008). Therapy with bone marrow cells reduces liver alterations in mice chronically infected by S. mansoni. World J Gastroentero 114(38):5842-5850

34) Puglisi, M. A., Saulnier, N., Piscaglia, A. C., Tondi, P., Agnes, S., \& Gasbarrini, A. (2011). Adipose tissue-derived mesenchymal stem cells and hepatic differentiation: old concepts and future perspectives. Eur Rev Med Pharmacol Sci, 15(4), 355-64

35) Salama, H., Zekri, A. R. N., Bahnassy, A. A., Medhat, E., Halim, H. A., Ahmed, O. S., ... \& Sherif, G. M. (2010). Autologous CD34+ and CD133+ stem cells transplantation in patients with end stage liver disease. World journal of gastroenterology: WJG, 16(42), 5297.

36) Santiago, E., de Oliveira, S. A., de Oliveira Filho, G. B., Moreira, D. R., Gomes, P. A., da Silva, A. L., ... Leite, A. C. (2014). Evaluation of the antiSchistosoma mansoni activity of thiosemicarbazones and thiazoles. Antimicrobial agents and chemotherapy, 58(1), 352-363. doi:10.1128/AAC.01900-13

37) Tondreau, T., Lagneaux, L., Dejeneffe, M., Massy, M., Mortier, C., Delforge, A., \& Bron, D. (2004). Bone marrow-derived mesenchymal stem cells already express specific neural proteins before any differentiation. Differentiation, 72(7), 319-326.

38) Wang X, Foster M, Al-Dhalimy M, Lagasse E, et al (2003). The origin and liver repopulating capacity of murine oval cells. Proc Nutl Acad SA USA 100(1):11881-11888

39) World Health Organization (WHO) (2012). Schistosomiasis: epidemiological situation. World Health Organization, Geneva Switzerland: http:// www.who.int/schistosomiasis/epidemiology/en/

40) Wu, Y., Wang, J., Scott, P. G., \& Tredget, E. E. (2007). Bone marrow-derived stem cells in wound healing: a review. Wound Repair and Regeneration, 15, S18-S26. 
41) Xiang, G. A., Zhang, G. Q., Fang, C. H., Gao, P., \& Chen, K. Y. (2005). A preliminary study of the homing capacity of allograft mesenchymal stem cells to rat liver. Di 1 jun yi da xue xue bao= Academic journal of the first medical college of PLA, 25(8), 994-997.

42) Zhao, D. C., Lei, J. X., Chen, R., Yu, W. H., Zhang, X. M., Li, S. N., \& Xiang, P. (2005). Bone marrow-derived mesenchymal stem cells protect against experimental liver fibrosis in rats. World journal of gastroenterology: WJG, 11(22), 3431.

43) Zhao, W. C., Zhang, H. B., Yang, N., Fu, Y., Qian, W., Chen, B. D., ... \& Yang, G. S. (2012). Preoperative predictors of short-term survival after hepatectomy for multinodular hepatocellular carcinoma. World journal of gastroenterology: WJG, 18(25), 3272.

44) Zhu, W., Shi, X. L., Xiao, J. Q., Gu, G. X., Ding, Y. T., \& Ma, Z. L. (2013). Effects of xenogeneic adipose-derived stem cell transplantation on acute-on-chronic liver failure. Hepatobiliary \& Pancreatic Diseases International, 12(1), 60-67. 
Table (1): Comparison between granuloma size measurements (H\&E sections), area percentage of collagen fibres (Mallory stained sections) and area percentage of positive OV-6 cells (IHC stained sections) in groups II, III and group IV

\begin{tabular}{|c|c|c|c|c|}
\hline & $\begin{array}{c}\text { Group I } \\
\text { (Control } \\
\text { group) } \\
\mathbf{N}=\mathbf{1 0}\end{array}$ & $\begin{array}{c}\text { Group II } \\
\text { (SCHISTOSOMA } \\
\text { GROUP) }\end{array}$ & $\begin{array}{l}\text { Group III } \\
\text { (BMSCs } \\
\text { treated } \\
\text { group) }\end{array}$ & $\begin{array}{c}\text { Group IV } \\
\text { (untreated group) }\end{array}$ \\
\hline $\begin{array}{l}\text { Granuloma } \\
\text { size Area } \\
(\mu \mathrm{m} 2)\end{array}$ & & $\begin{array}{c}33064.4 \pm 9394.48 \\
\boldsymbol{\Delta}, \mathrm{O}\end{array}$ & $\begin{array}{r}5551.1 \pm \\
1338.26 \\
\square, O\end{array}$ & $\begin{array}{c}625377.78 \pm 23900.4 \\
\text { •, } \boldsymbol{\Delta}\end{array}$ \\
\hline $\begin{array}{l}\text { Area } \\
\text { percentage } \\
\text { of collagen } \\
\text { fibers }(\%)\end{array}$ & $\begin{array}{l}1.48 \pm \\
.35 \\
\boldsymbol{\Delta} \mathrm{O}\end{array}$ & $\begin{array}{c}14.46 \pm 2.47 \\
* \boldsymbol{\Delta} \mathrm{O}\end{array}$ & $\begin{array}{c}6.56 \pm 1.34 \\
* \square\end{array}$ & $\begin{array}{c}31.145 \pm 5.91 \\
* \square \Delta\end{array}$ \\
\hline $\begin{array}{l}\text { Area } \\
\text { percentage } \\
\text { of OV-6 }(\%)\end{array}$ & $\begin{array}{c}1.57 \\
\pm 0.22 \\
\mathbf{\Delta} \mathbf{\Delta O}\end{array}$ & $\begin{array}{c}8.45 \pm 1.77 \\
* \boldsymbol{\Lambda}\end{array}$ & $\begin{array}{l}20.39 \pm 4.10 \\
* \square \mathrm{O}\end{array}$ & $\begin{array}{c}7.05 \pm 1.55 \\
* \Delta\end{array}$ \\
\hline
\end{tabular}

* Significant difference from group I.

- Significant difference from group II.

$\boldsymbol{\Delta}$ Significant difference from group III.

O Significant difference from group IV. 

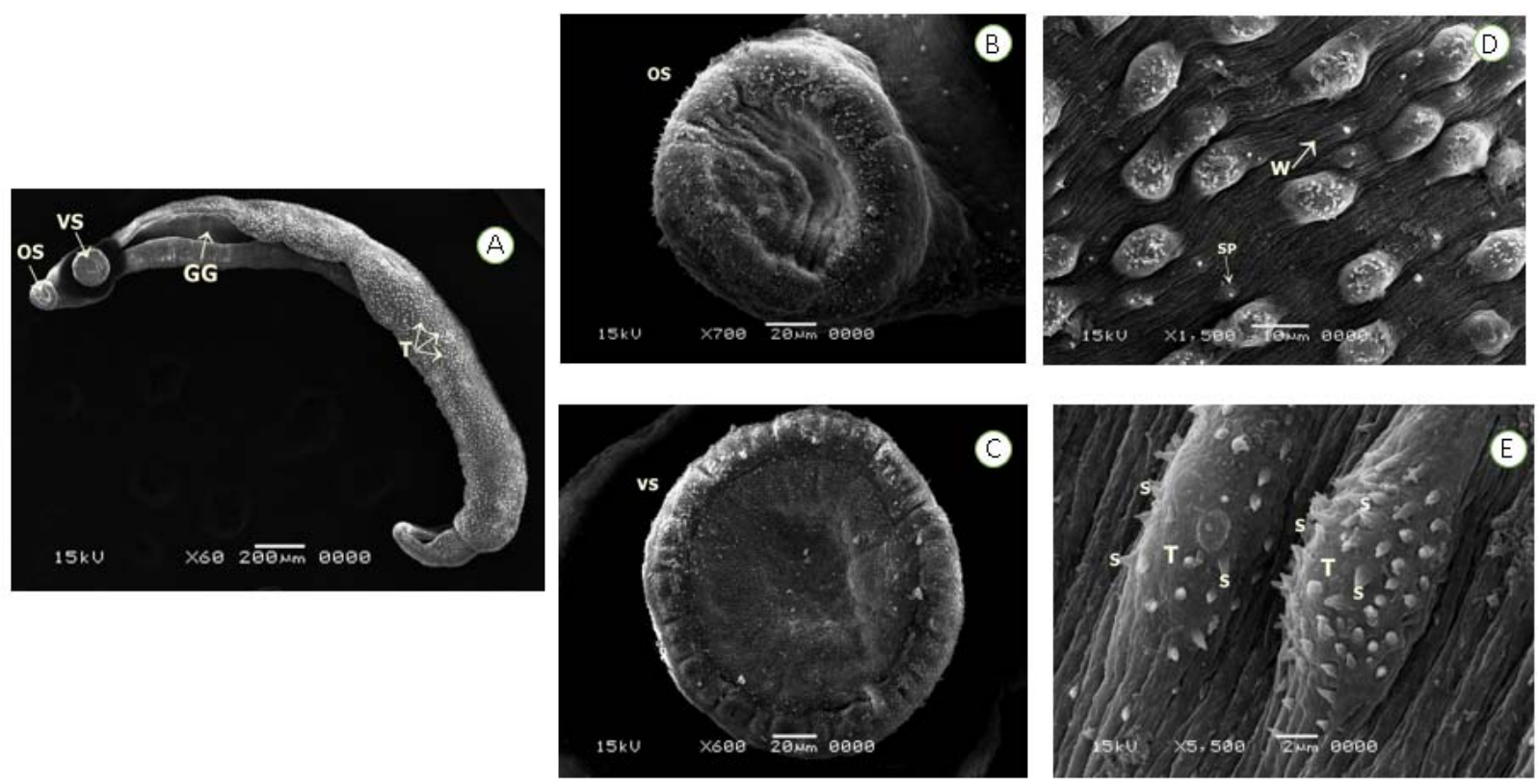

Fig. (1): A: Male worms show the anterior portion of the body with oral (OS) and ventral suckers (VS) and the gynecophoral canal (GC) with no abnormalities. The dorsal region of male worms showing numerous tubercles (T) distributed along the body. B: superior and inferior borders of the oral sucker (OS). C: ventral sucker (VS) is bigger and more prominent than the OS. Both surfaces at this site did not present spines. D: in detail the dorsal region with sensory papillae (SP) and parallel wrinkles (W) visible. E: Higher magnification showing in detail numerous spines (S) covering the tubercules $(\mathrm{T})$. 

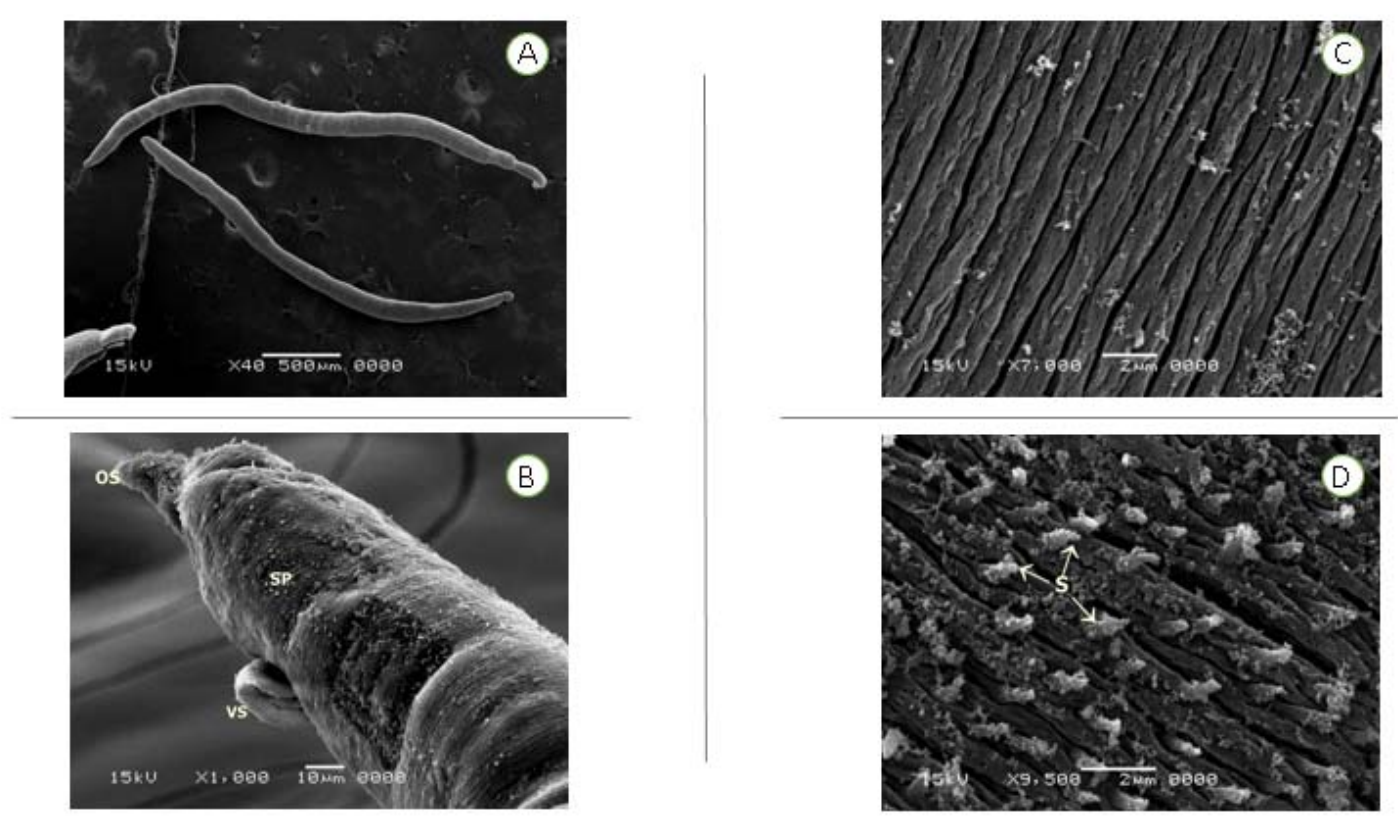

Fig. (2): A: Female worm shows the whole extent of the body. B: Female worm showing the oral (OS), ventral (VS) suckers, the sensory papillae (SP) and the integrity of the tegument. C: spines (S) in detail. D: Higher magnification Female worms showing spines $(\mathrm{S})$ in detail. 


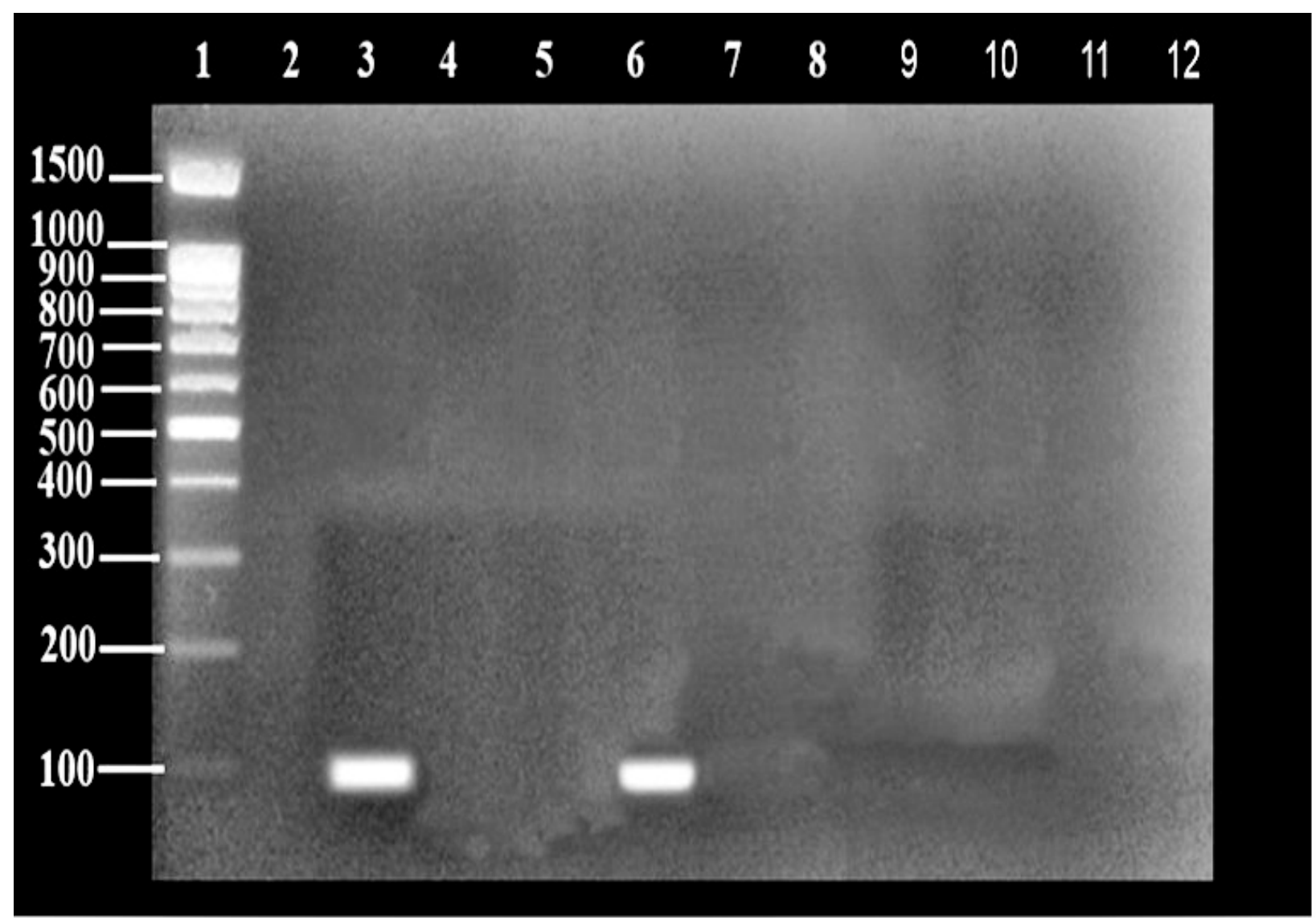

Fig. (3): PCR analysis for Sry gene in liver homogenate of female mice groups. Lane 1: DNA molecular weight marker. Lane 2: Negative PCR control (female mice liver DNA). Lane 3: positive PCR control (male mice liver). Lane 4: Gr I. Lane 5: Gr II. Lane 6: Gr III. Lane 7: Gr IV. 

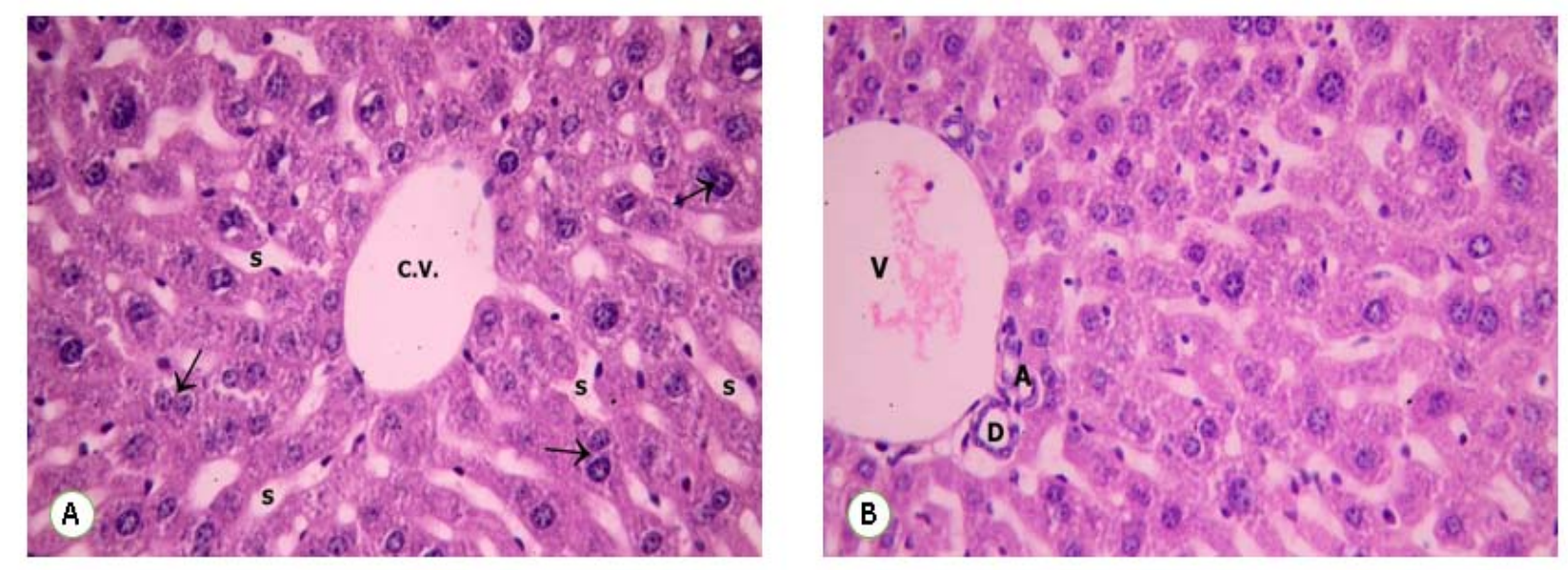

Fig. 4: Photomicrographs of liver sections of control group I show: A: polyhedral hepatocytes with acidophilic cytoplasm and vesicular nuclei ( $\uparrow)$. They are arranged as cords separated by blood sinusoids (S). These cords appear radiating from the central vein (CV). B: The portal tract containing a hepatic artery (A), portal vein (V) and a bile duct (D) can be also seen. $H \& E, x 400$ 

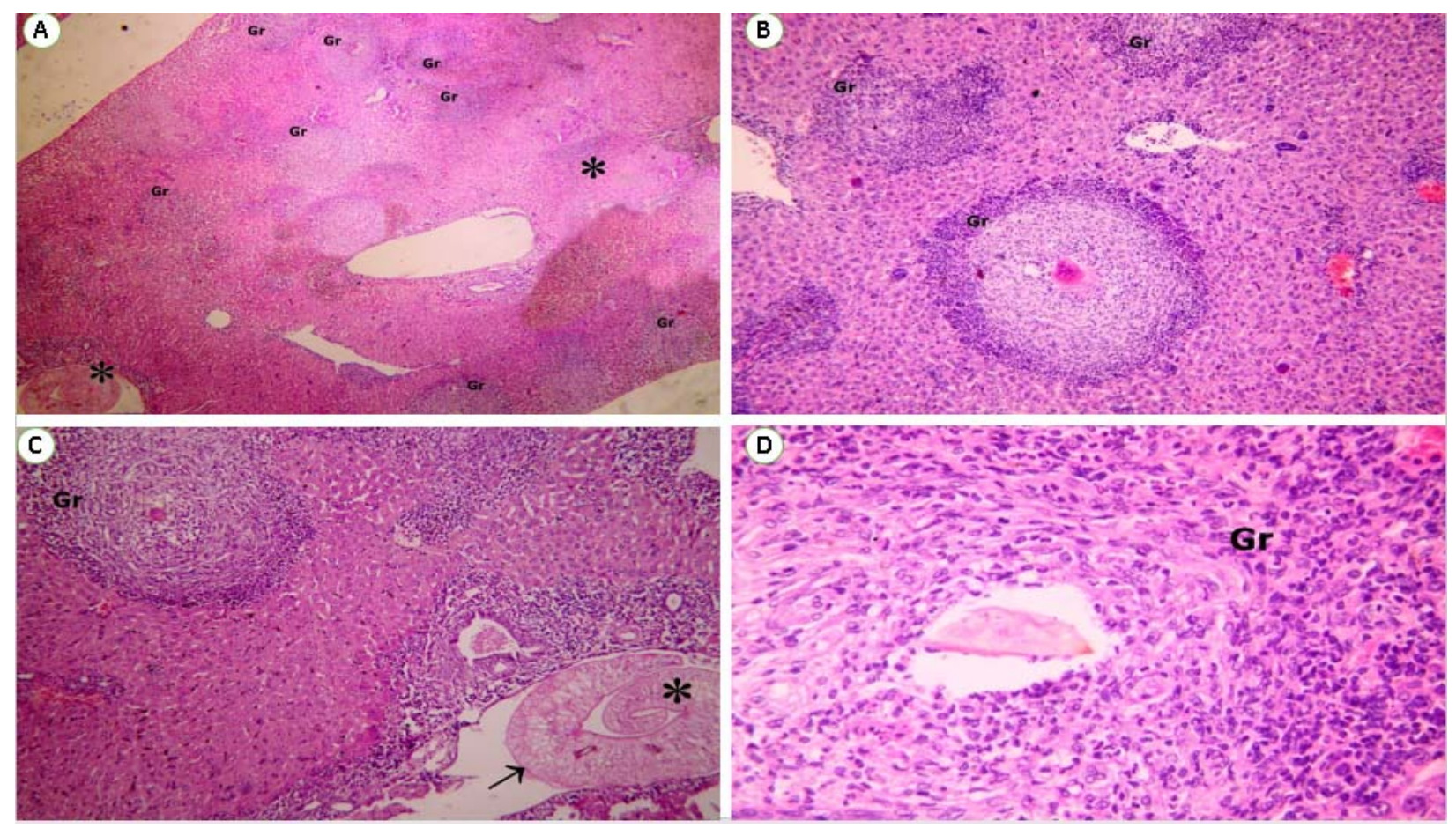

Fig. 5: Photomicrographs of liver sections of group II (Schistosoma alone) show: A \& B: multiple, large sized, cellular schistosomal granulomas (Gr) with inflammatory cellular infiltrate. $\mathrm{H} \& \mathrm{E}, \mathrm{x} 100,200$. C: Adults Schistosoma (*) shows the tuberculate exterior ( $\uparrow$ ) H\&E, x200. C: the presence of large Schistosomal granuloma (Gr) around egg with marked inflammatory cells H\&E, $\mathrm{x} 400$. 

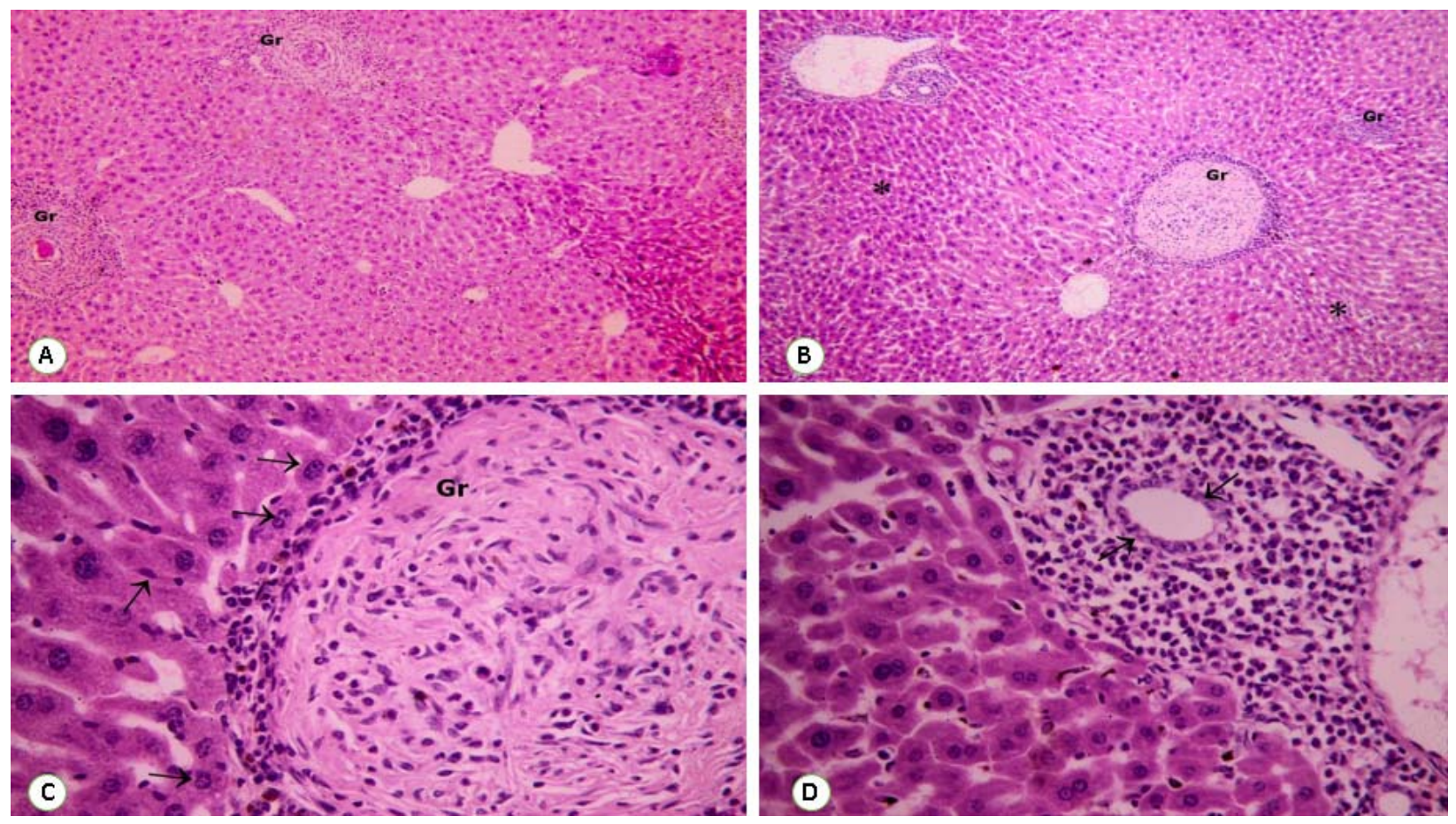

Fig. 6: Photomicrographs of liver sections of group III (treated with BMSCs: A \& B: show a significant reduction in granuloma size. Note the decrease of peripheral inflammatory cellular infiltrate with normal hepatic tissue in-between (*) H\&E, x100, 200. C: show the presence of newly formed hepatocytic cells with relatively rounded to elongated large dark nuclei $(\uparrow)$ at the periphery of the granuloma (Gr) H\&E, x400. D: show proliferating hepatic duct lined with columnar cells having basal nuclei $(\uparrow) \mathrm{H} \& \mathrm{E}, \mathrm{x} 400$. 

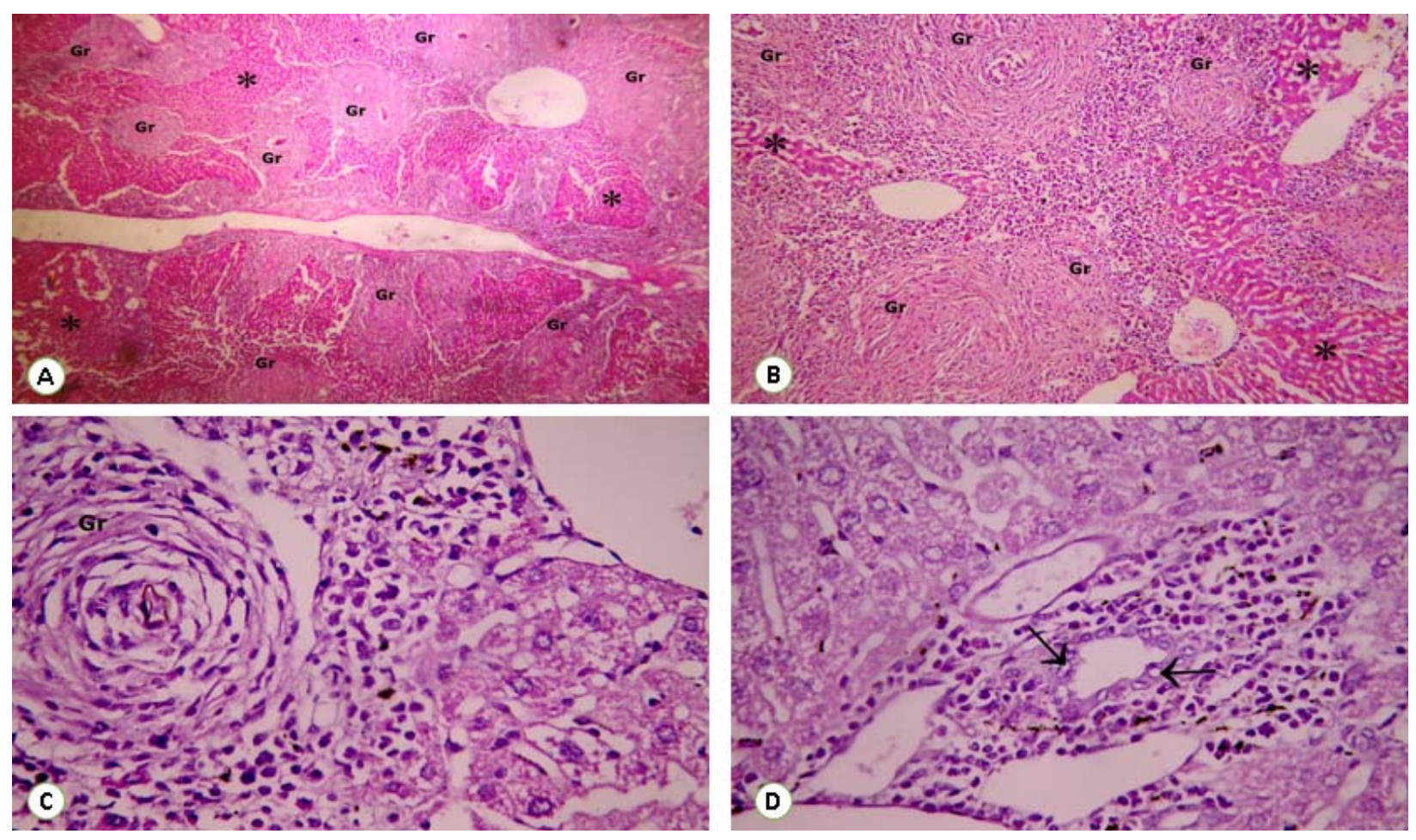

Fig. 7: Photomicrographs of liver sections of group IV (Untreated group): A \& B: show multiple coalescent characteristic fibrous schistosomal granulomas (Gr) with only few areas of hepatocytes (*) H\&E, x100, 200. C: show absent of newly formed hepatocytic cells with calcified ova in the granuloma (Gr) H\&E, x400. D: Show bile duct with highly vacuolated epithelium $(\uparrow)$ H\&E, $x 400$. 


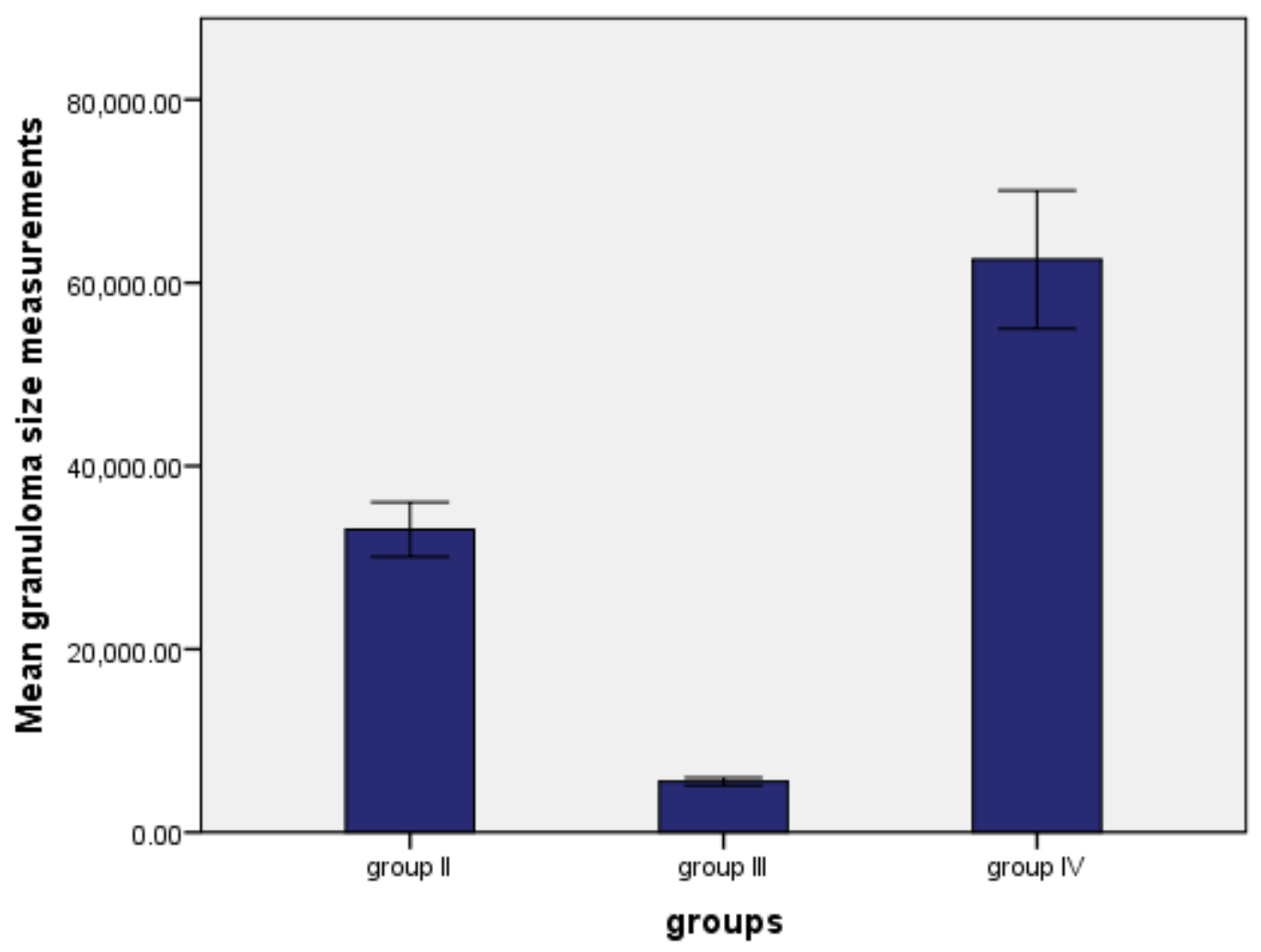

Fig. (8): Comparison between the different groups as regard dimension of granuloma. 


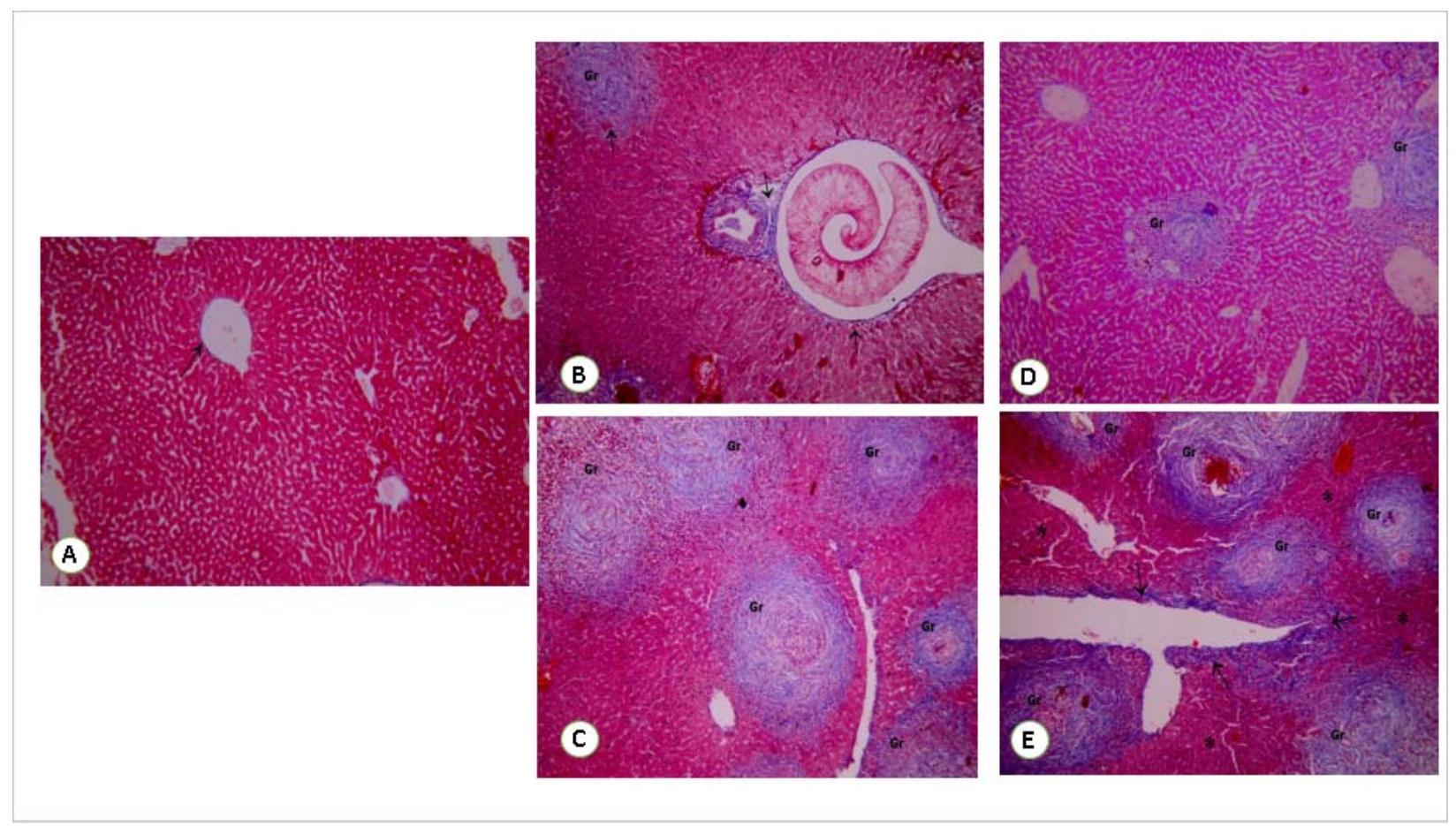

Fig. (9): Liver tissue section from: A: Group I (control group), show few collagen fibers around central veins ( $\uparrow$ ). B \& C: Group II (Schistosoma group) show multiple large coalescent schistosomal granuloma (Gr) with increased degree of fibrosis around portal vein with impacted adult worm inside it ( $\uparrow)$. D: Group III (treated with BMSCs) show a significant decrease in granuloma $(\mathrm{Gr})$ size and the degree of fibrosis. E: Group IV (Untreated group) show multiple large coalescent schistosomal granuloma $(G)$ with increased degree of fibrosis $(\uparrow)$ around portal vein and sparing only few areas of hepatic tissue (*) Mallory stain x100). 

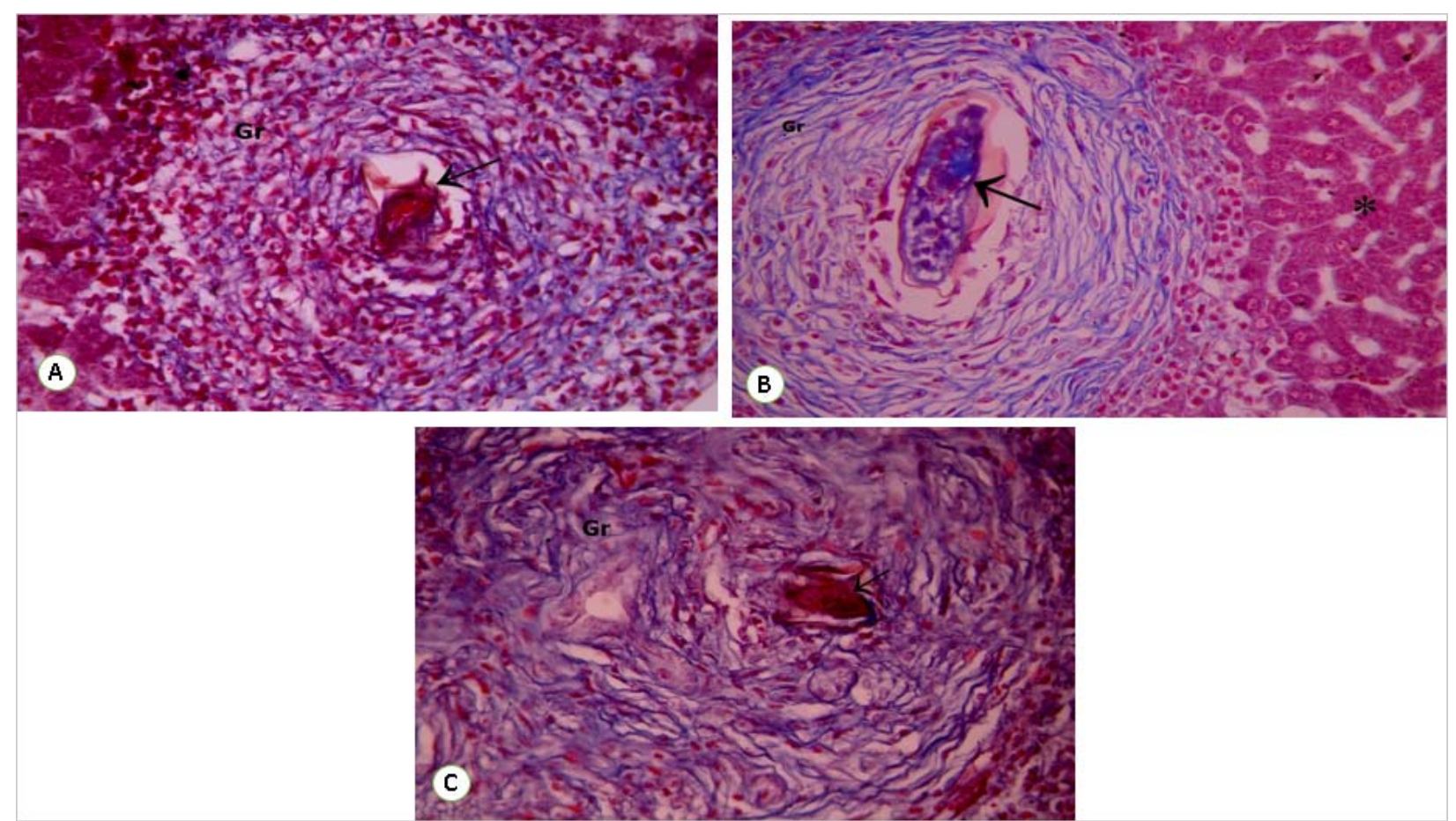

Fig. (11): Liver tissue section from: A: Group II (Schistosoma group) show large schistosomal granuloma (Gr) with marked inflammatory cells and Schistosoma egg $(\uparrow)$. B: Group III (treated with BMSCs) show granuloma (Gr) with well-organized fibrous tissue, calcified Schistosoma egg $(\uparrow)$ and sparing most of the hepatic tissue (*). C: Group IV (Untreated group) show large schistosomal granuloma (Gr) with increased degree of fibrosis around Schistosoma egg $(\uparrow)$ Mallory stain x400). 


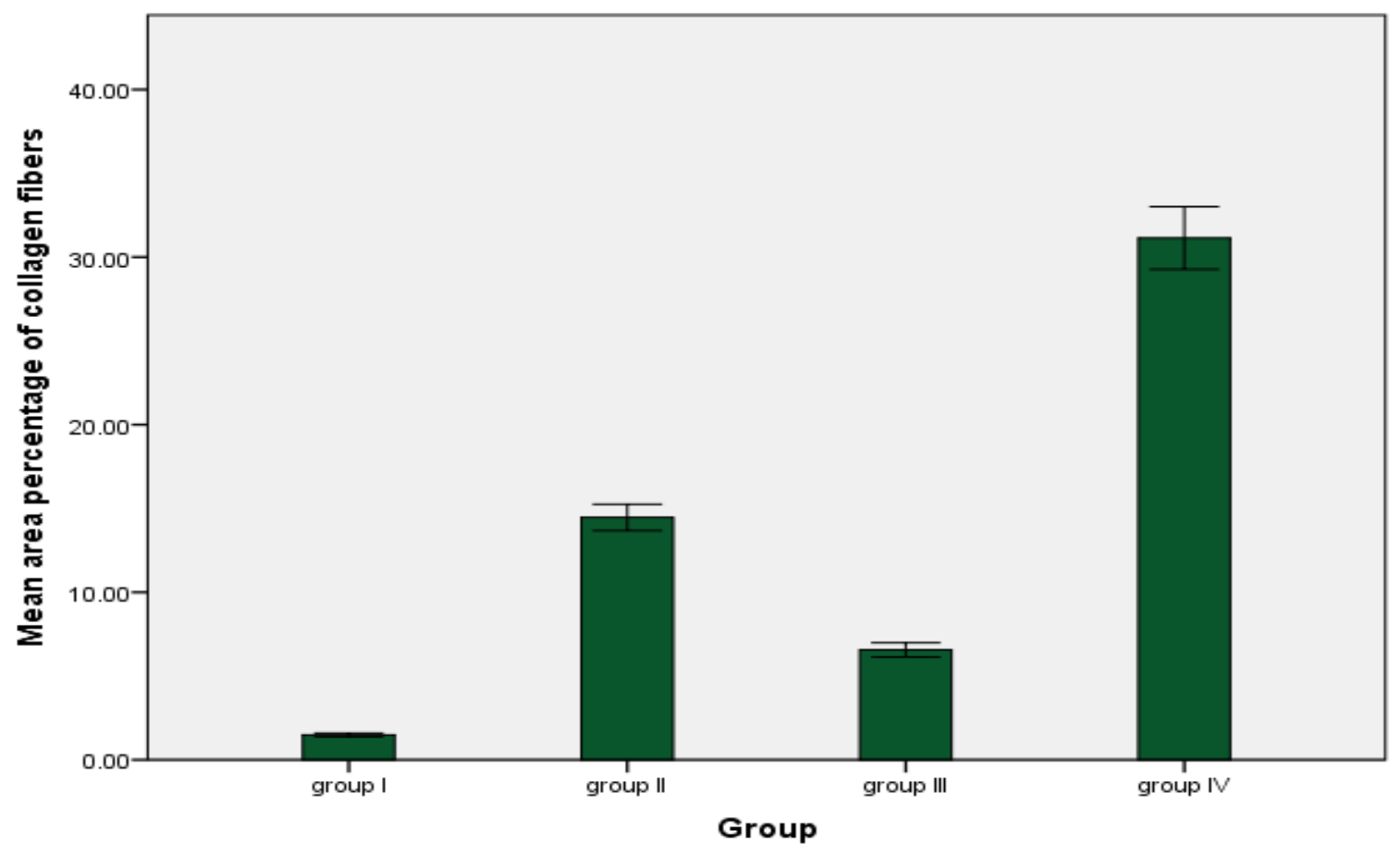

Fig. (11): The mean values of the area percentage of collagen fibers among the different study groups. 

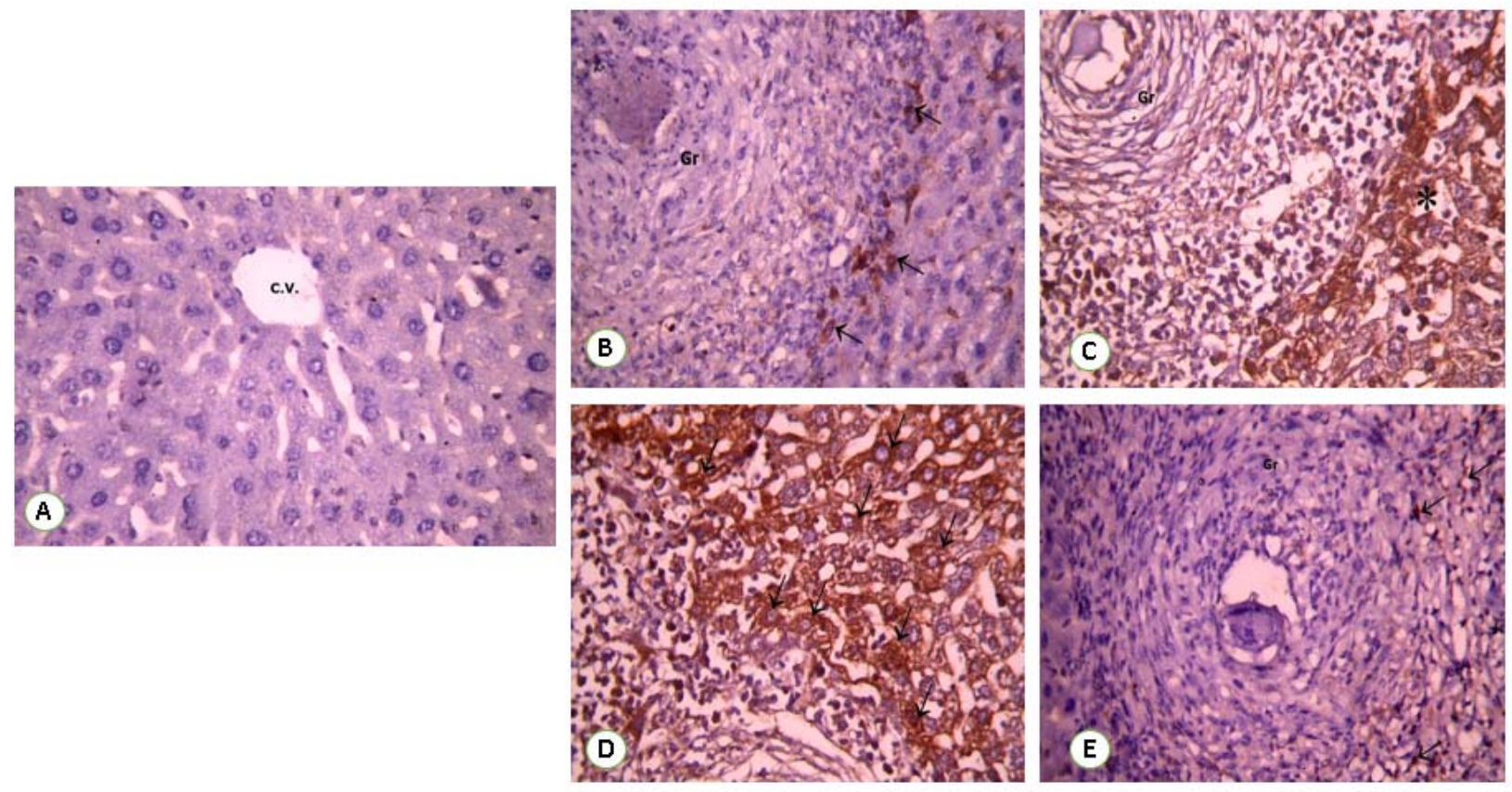

Fig. (12): Immunostaining for OV-6 antibody in a liver section of: A: Group I (Control group) show negative expression of OV-6. Group B: show few positive expressions of OV-6 C \&D: Group III (treated with BMSCs) show expression of OV6 monoclonal antibody as cytoplasmic brownish color $(\uparrow)$ in hepatocytes like cells (*) and granuloma cells (Gr). E: Group IV (Untreated group) show few positive expressions of OV-6 ( $\uparrow)$ (IHC, DAB, x400). 


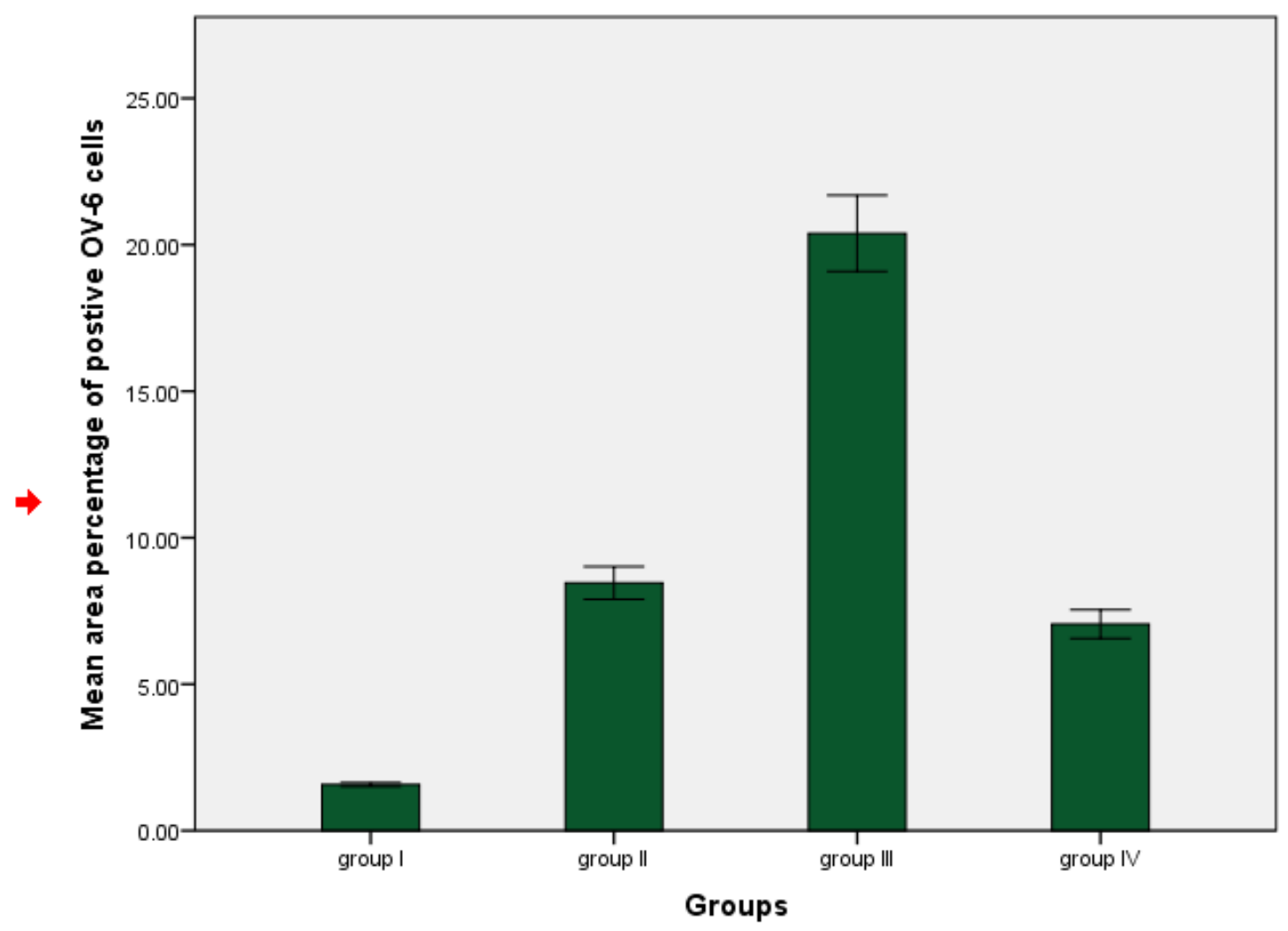

Fig. (13): The mean values of the area percentage of positive cells of OV-6 among the different study groups. 

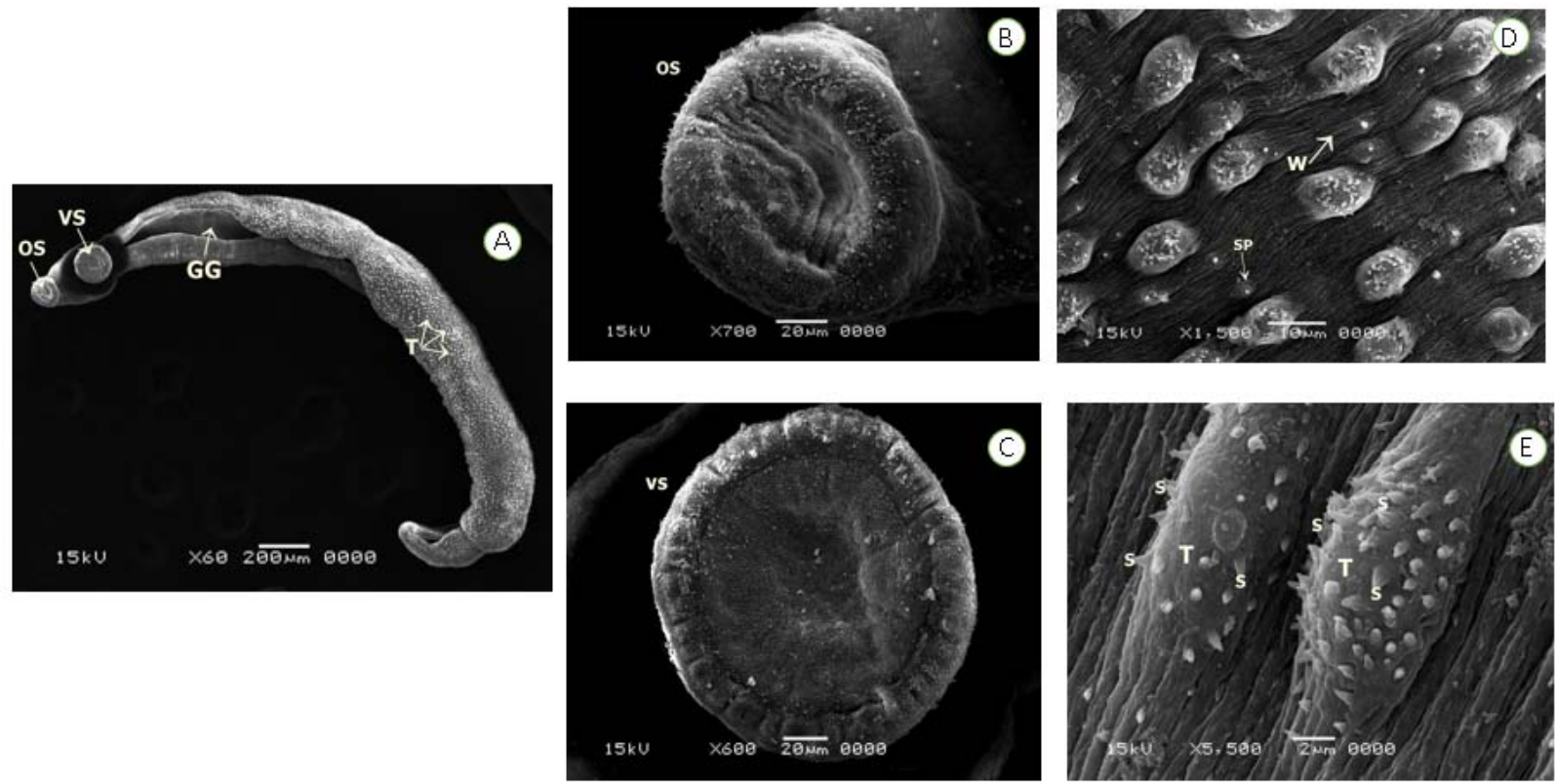

Fig. (1): A: Male worms show the anterior portion of the body with oral (OS) and ventral suckers (VS) and the gynecophoral canal (GC) with no abnormalities. The dorsal region of male worms showing numerous tubercles (T) distributed along the body. B: superior and inferior borders of the oral sucker (OS). C: ventral sucker (VS) is bigger and more prominent than the OS. Both surfaces at this site did not present spines. D: in detail the dorsal region with sensory papillae (SP) and parallel wrinkles (W) visible. E: Higher magnification showing in detail numerous spines $(\mathrm{S})$ covering the tubercules $(\mathrm{T})$. 

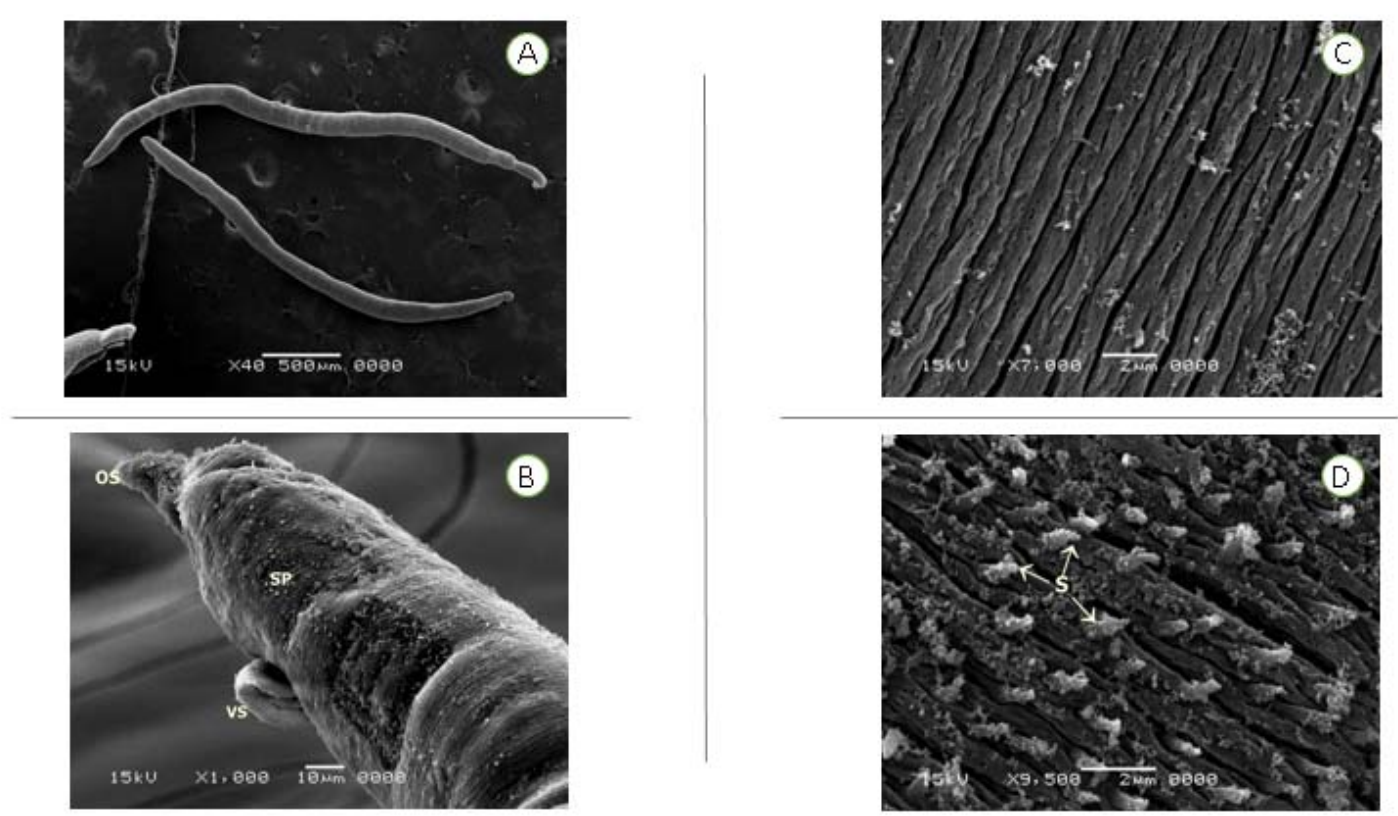

Fig. (2): A: Female worm shows the whole extent of the body. B: Female worm showing the oral (OS), ventral (VS) suckers, the sensory papillae (SP) and the integrity of the tegument. C: spines (S) in detail. D: Higher magnification Female worms showing spines $(\mathrm{S})$ in detail. 


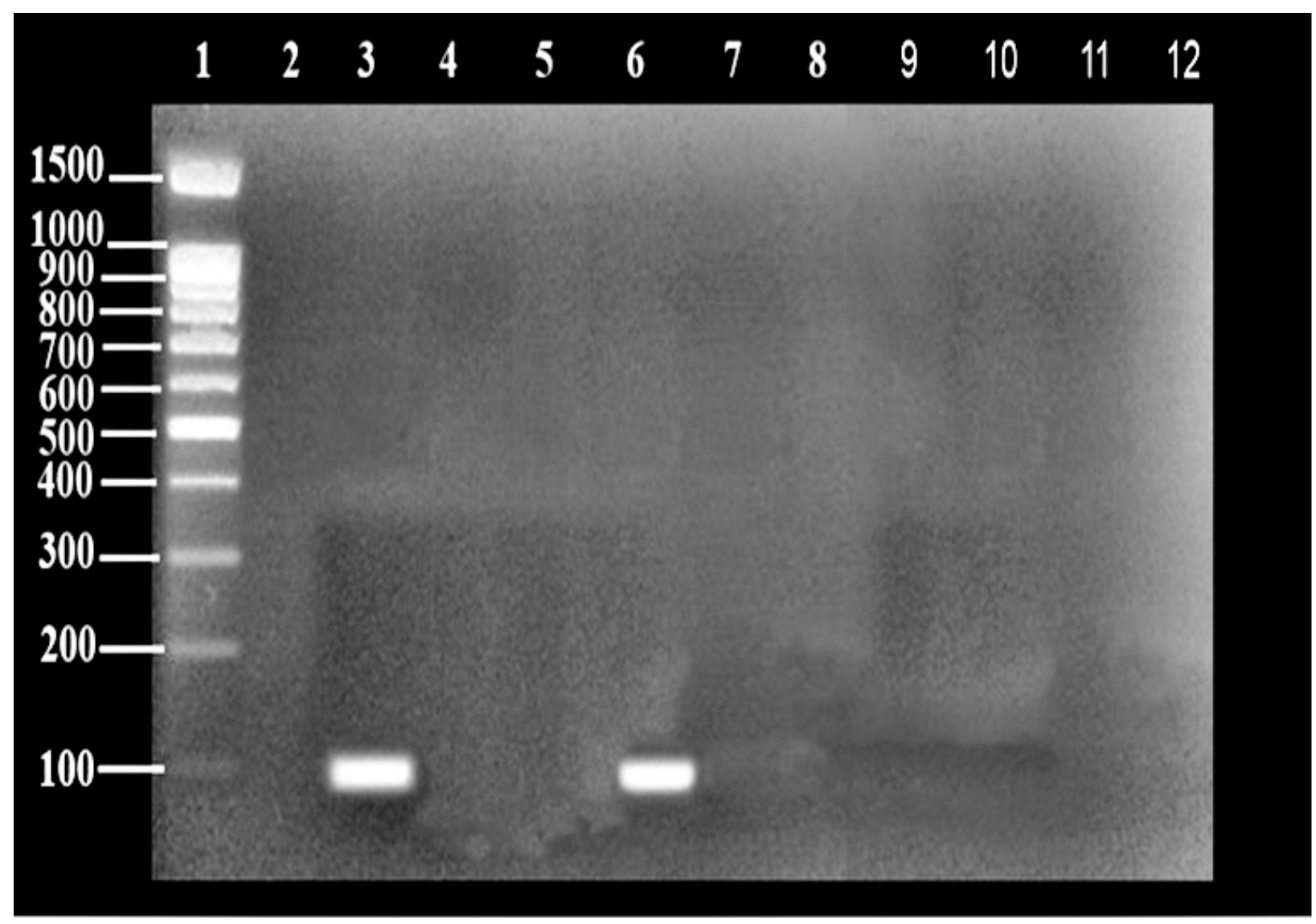

Fig. (3): PCR analysis for Sry gene in liver homogenate of female mice groups. Lane 1: DNA molecular weight marker. Lane 2: Negative PCR control (female mice liver DNA). Lane 3: positive PCR control (male mice liver). Lane 4: Gr I. Lane 5: Gr II. Lane 6: Gr III. Lane 7: Gr IV. 

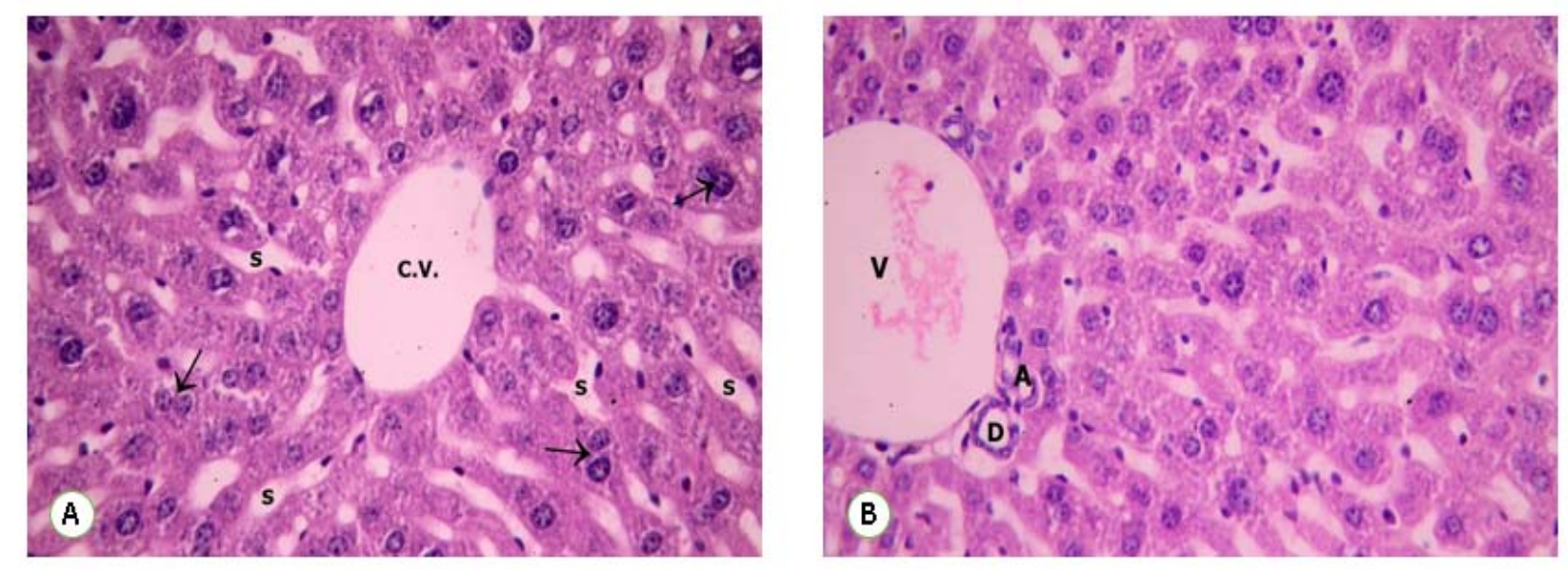

Fig. 4: Photomicrographs of liver sections of control group I show: A: polyhedral hepatocytes with acidophilic cytoplasm and vesicular nuclei ( $\uparrow)$. They are arranged as cords separated by blood sinusoids (S). These cords appear radiating from the central vein (CV). B: The portal tract containing a hepatic artery (A), portal vein (V) and a bile duct (D) can be also seen. $H \& E, x 400$ 

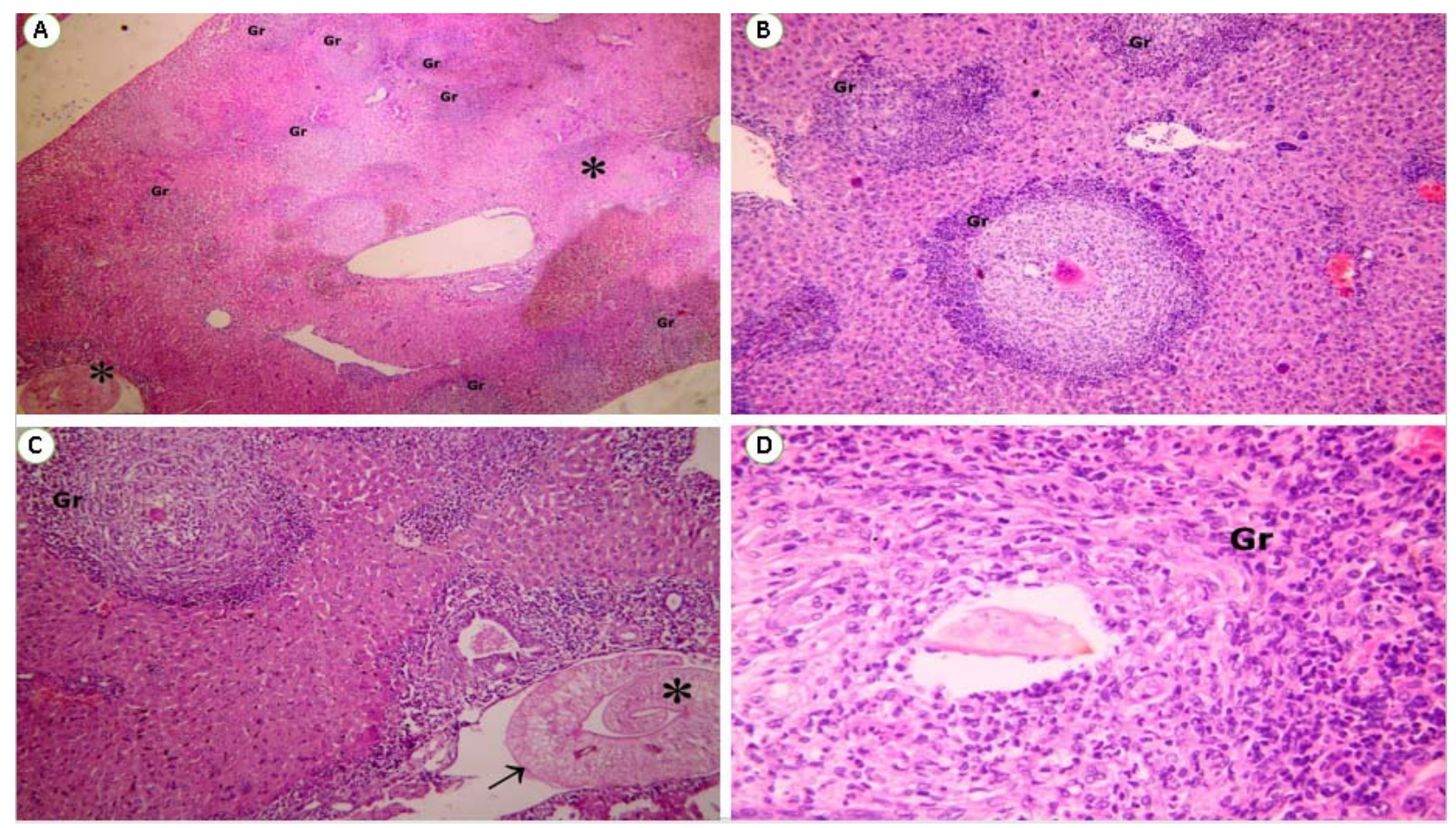

Fig. 5: Photomicrographs of liver sections of group II (Schistosoma alone) show: A \& B: multiple, large sized, cellular schistosomal granulomas (Gr) with inflammatory cellular infiltrate. $\mathrm{H} \& \mathrm{E}, \mathrm{x} 100,200$. C: Adults Schistosoma (*) shows the tuberculate exterior ( $\uparrow$ ) H\&E, x200. C: the presence of large Schistosomal granuloma (Gr) around egg with marked inflammatory cells H\&E, $\mathrm{x} 400$. 

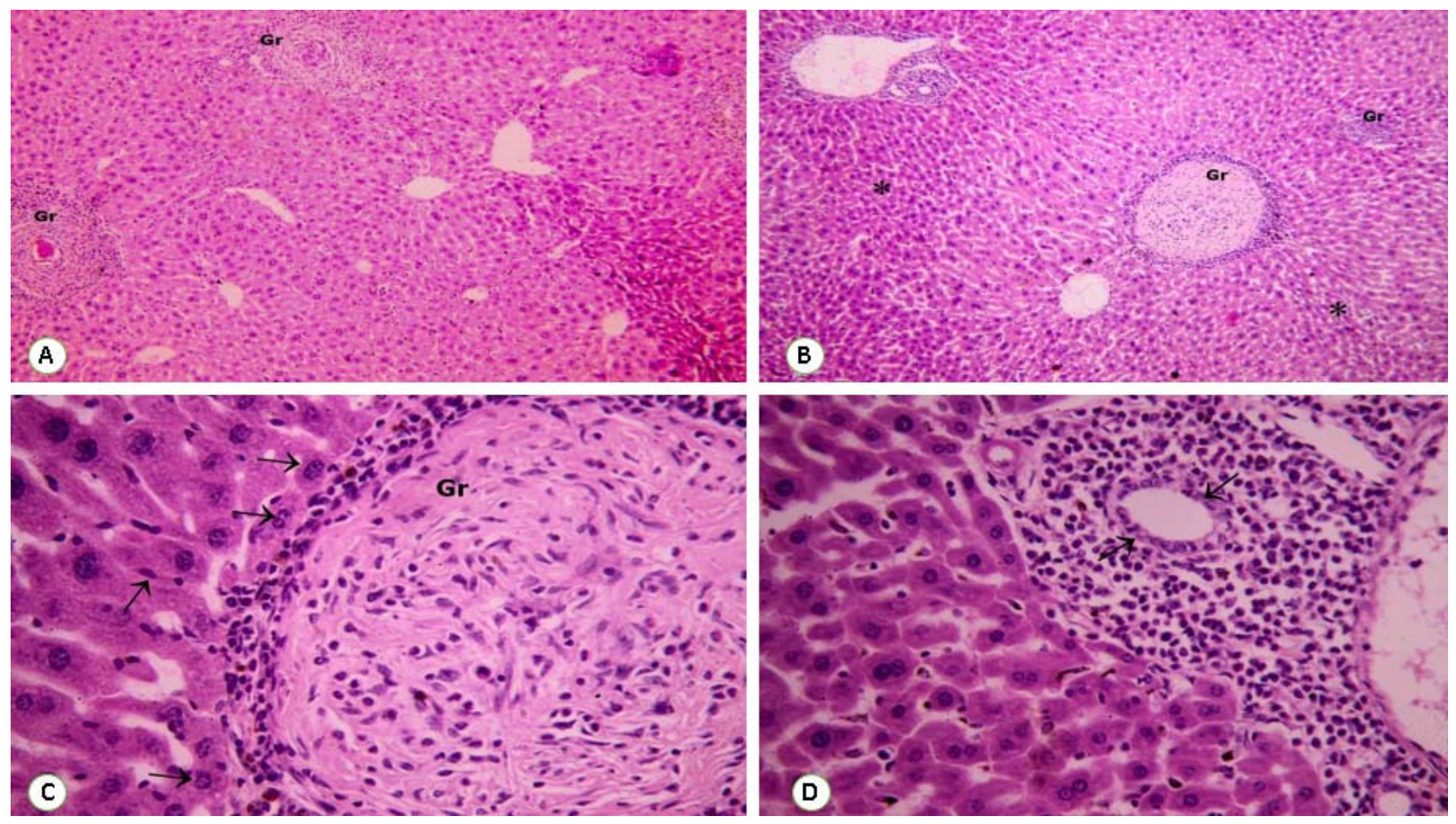

Fig. 6: Photomicrographs of liver sections of group III (treated with BMSCs: A \& B: show a significant reduction in granuloma size. Note the decrease of peripheral inflammatory cellular infiltrate with normal hepatic tissue in-between (*) H\&E, x100, 200. C: show the presence of newly formed hepatocytic cells with relatively rounded to elongated large dark nuclei $(\uparrow)$ at the periphery of the granuloma (Gr) H\&E, x400. D: show proliferating hepatic duct lined with columnar cells having basal nuclei $(\uparrow) \mathrm{H} \& \mathrm{E}, \mathrm{x} 400$. 

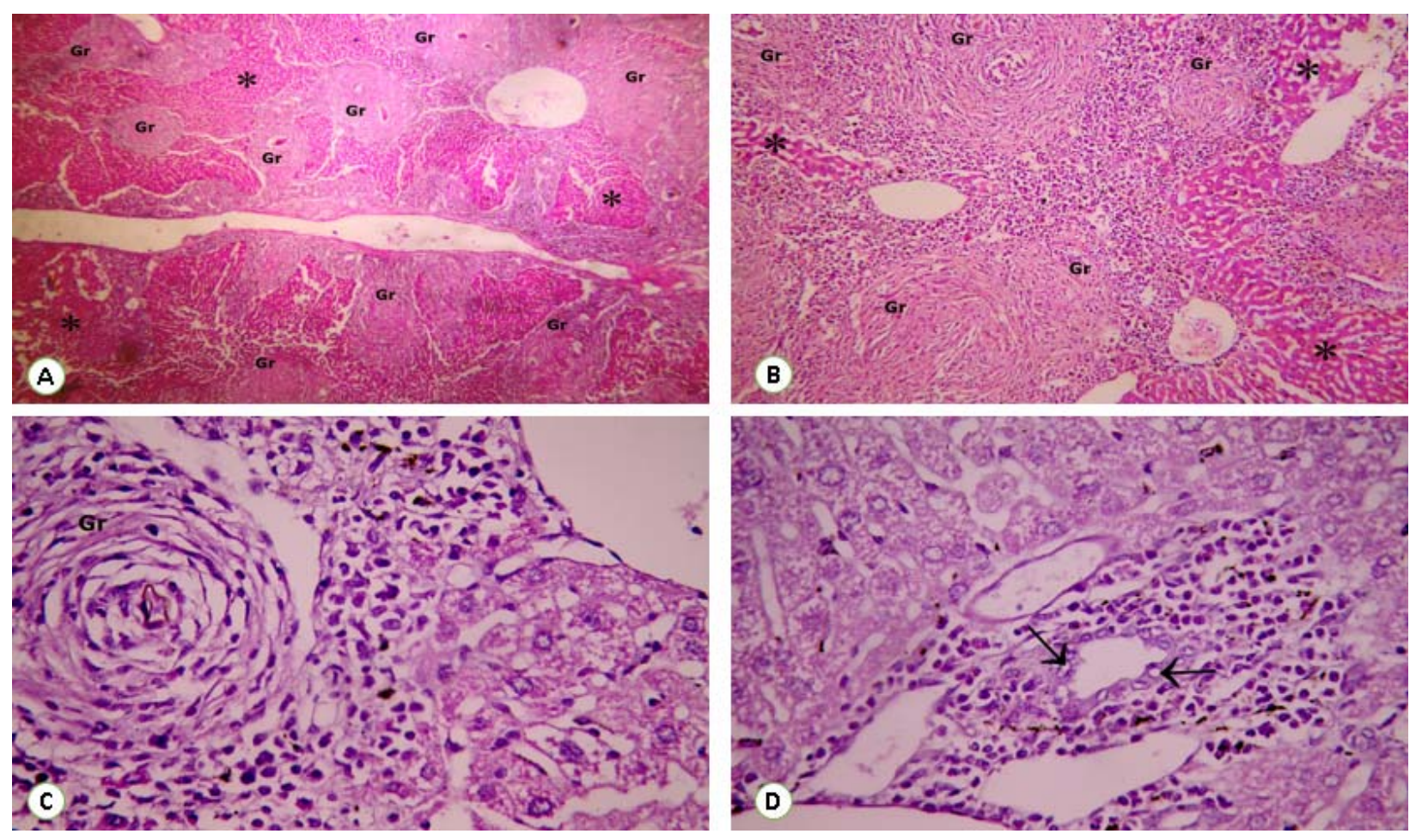

Fig. 7: Photomicrographs of liver sections of group IV (Untreated group): A \& B: show multiple coalescent characteristic fibrous schistosomal granulomas (Gr) with only few areas of hepatocytes (*) H\&E, x100, 200. C: show absent of newly formed hepatocytic cells with calcified ova in the granuloma (Gr) H\&E, x400. D: Show bile duct with highly vacuolated epithelium $(\uparrow)$ H\&E, $x 400$. 


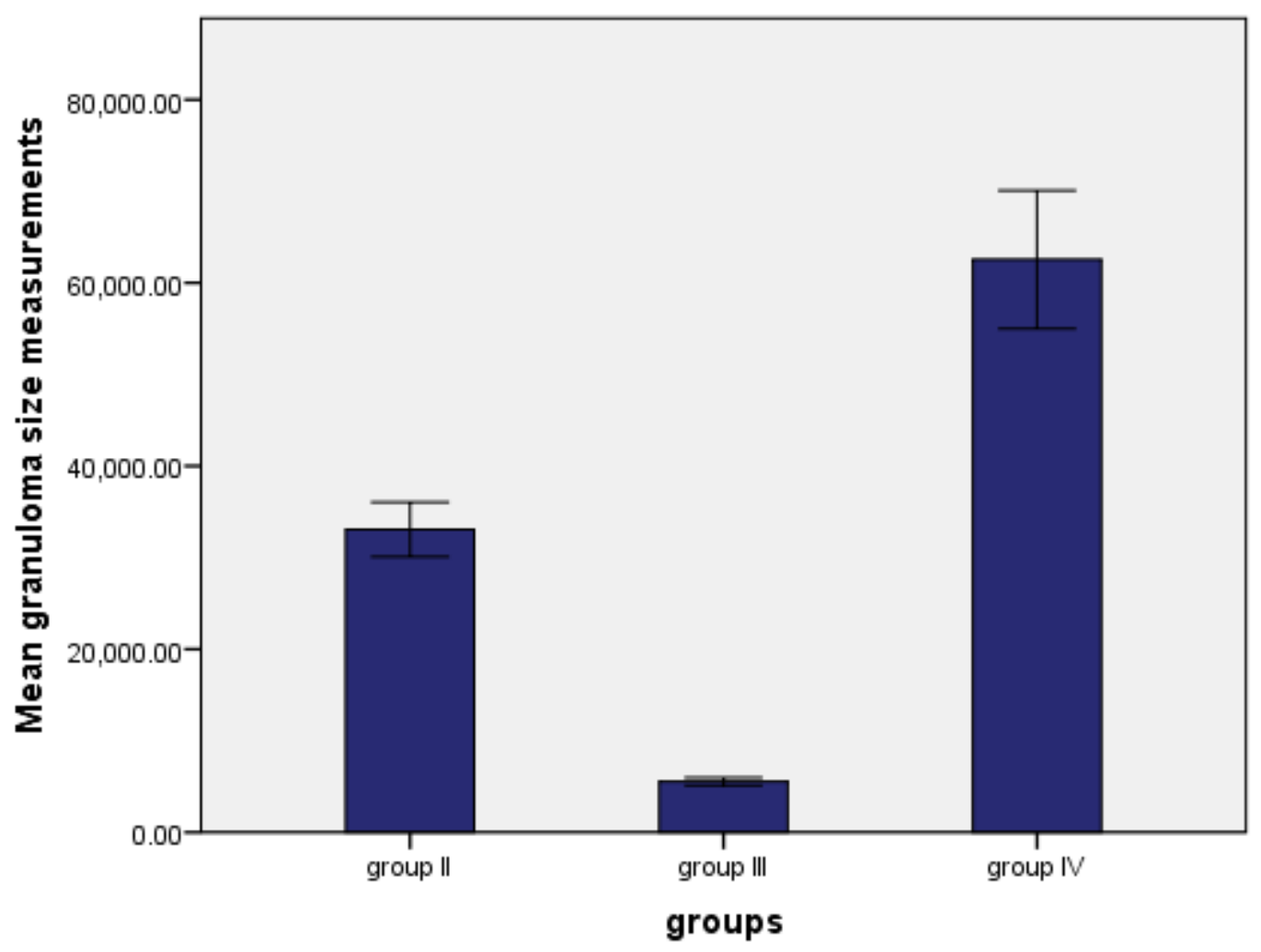

Fig. (8): Comparison between the different groups as regard dimension of granuloma. 


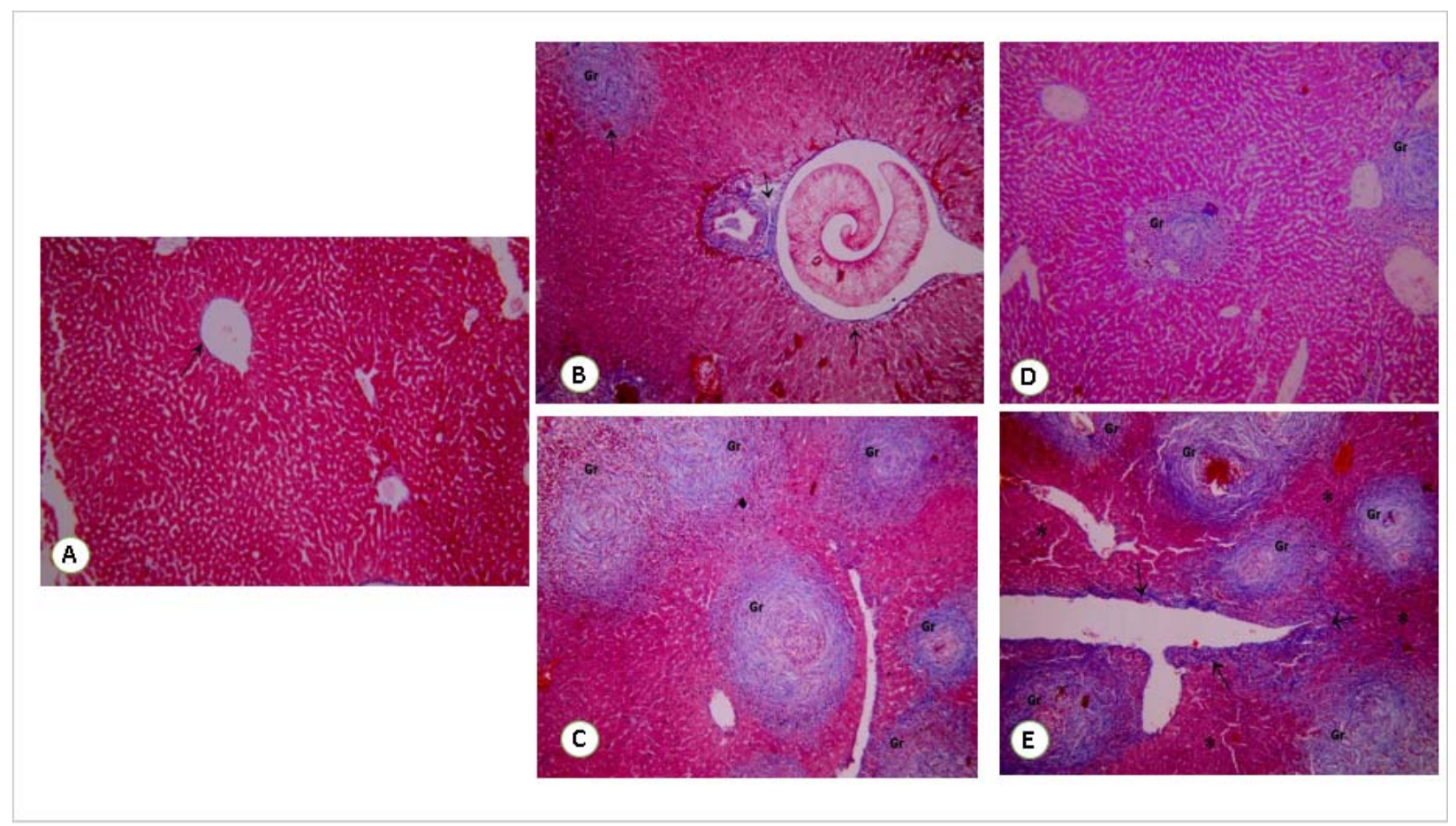

Fig. (9): Liver tissue section from: A: Group I (control group), show few collagen fibers around central veins ( $\uparrow$ ). B \& C: Group II (Schistosoma group) show multiple large coalescent schistosomal granuloma (Gr) with increased degree of fibrosis around portal vein with impacted adult worm inside it ( $\uparrow)$. D: Group III (treated with BMSCs) show a significant decrease in granuloma $(\mathrm{Gr})$ size and the degree of fibrosis. E: Group IV (Untreated group) show multiple large coalescent schistosomal granuloma $(G)$ with increased degree of fibrosis $(\uparrow)$ around portal vein and sparing only few areas of hepatic tissue (*) Mallory stain x100). 

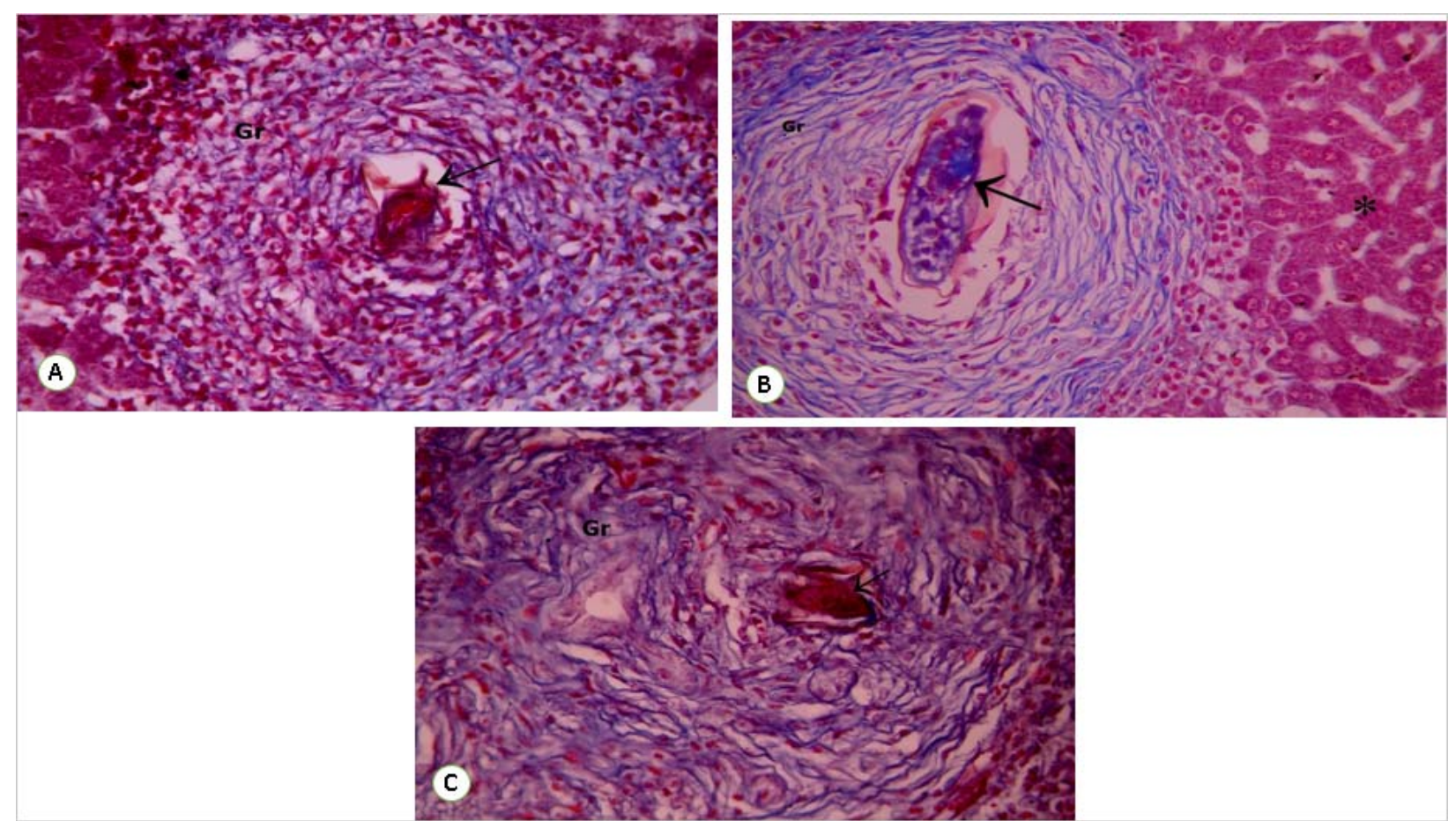

Fig. (11): Liver tissue section from: A: Group II (Schistosoma group) show large schistosomal granuloma (Gr) with marked inflammatory cells and Schistosoma egg $(\uparrow)$. B: Group III (treated with BMSCs) show granuloma (Gr) with well-organized fibrous tissue, calcified Schistosoma egg $(\uparrow)$ and sparing most of the hepatic tissue (*). C: Group IV (Untreated group) show large schistosomal granuloma (Gr) with increased degree of fibrosis around Schistosoma egg $(\uparrow)$ Mallory stain x400). 


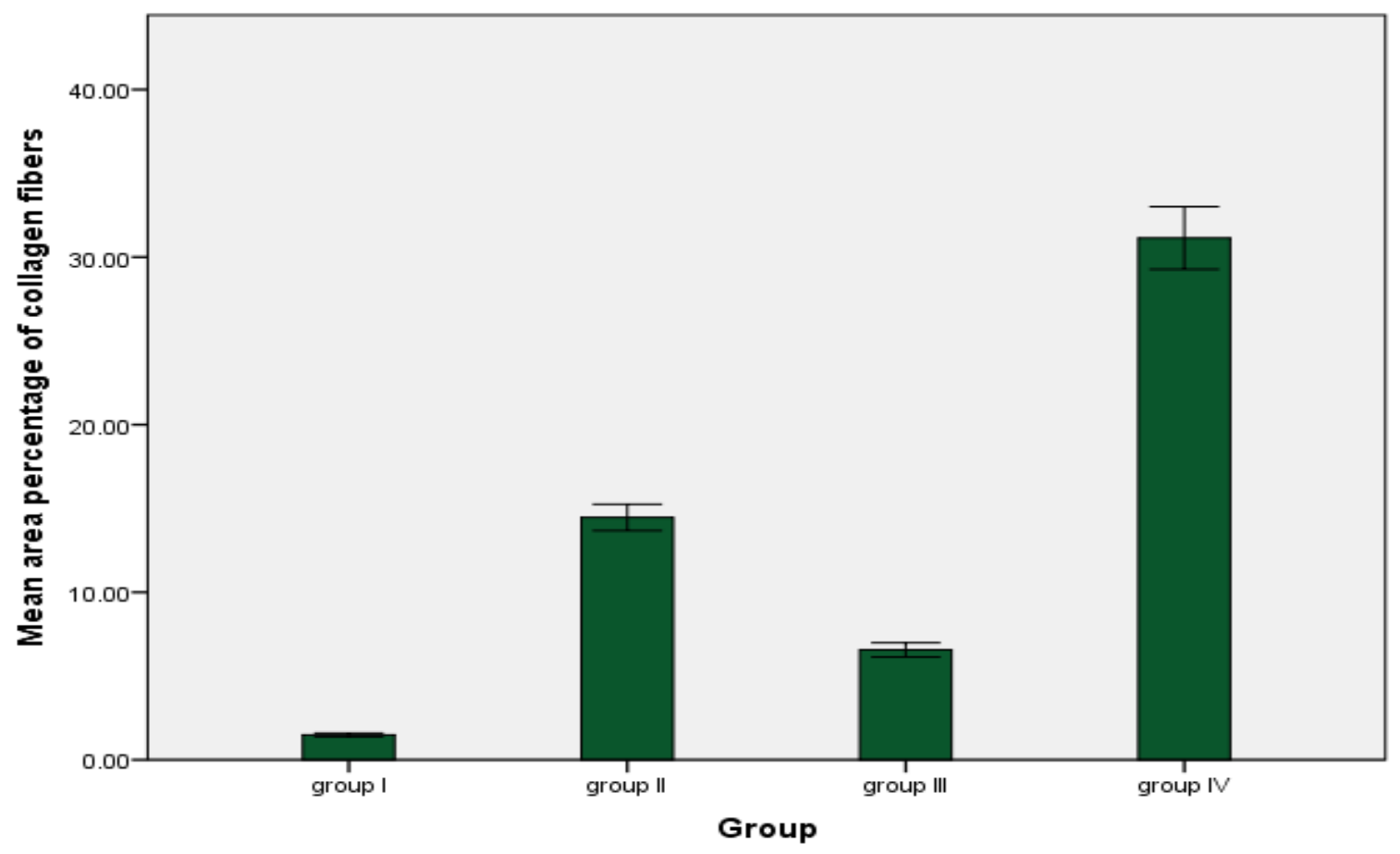

Fig. (11): The mean values of the area percentage of collagen fibers among the different study groups. 

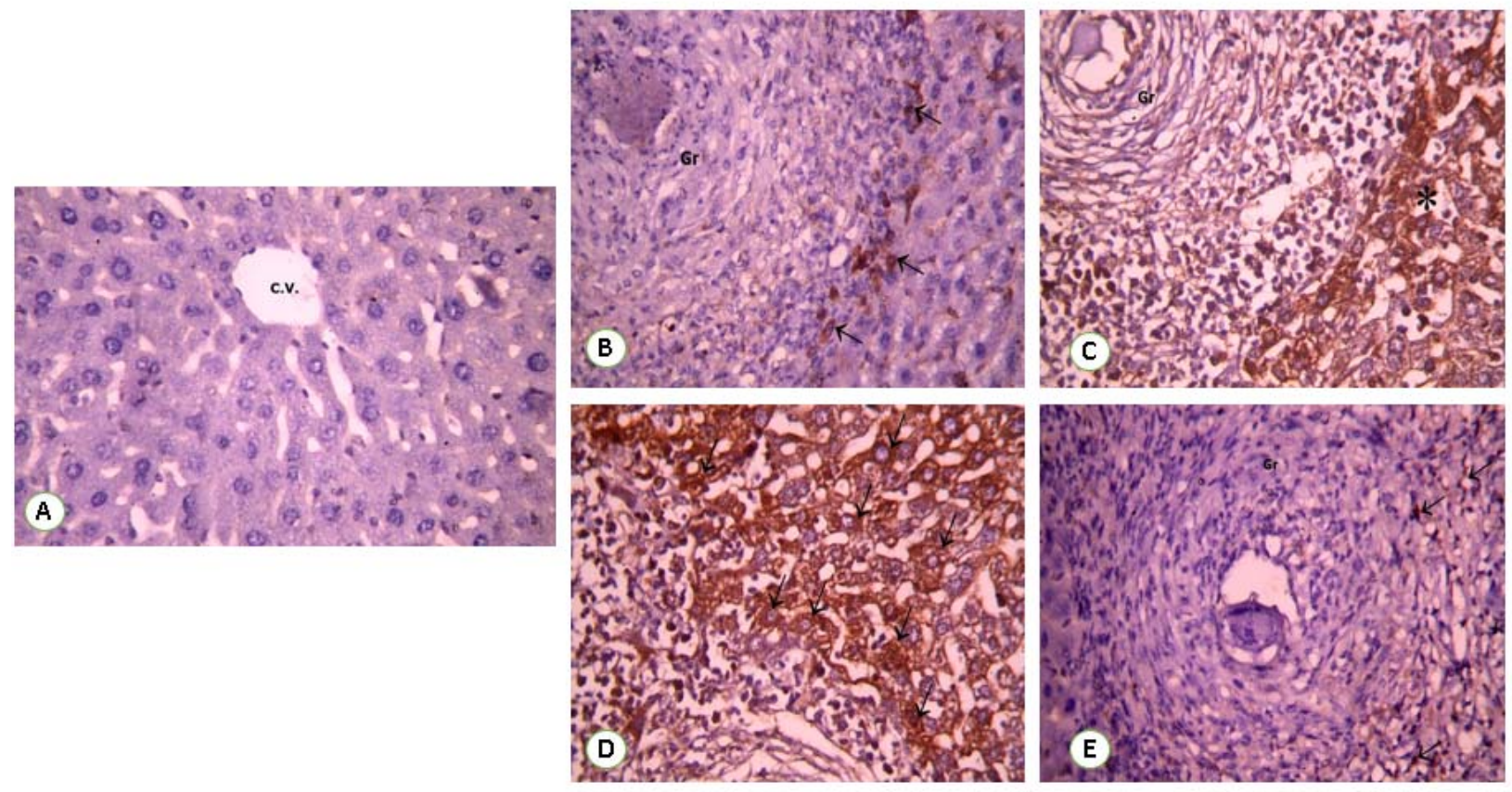

Fig. (12): Immunostaining for OV-6 antibody in a liver section of: A: Group I (Control group) show negative expression of OV-6. Group B: show few positive expressions of OV-6 C \&D: Group III (treated with BMSCs) show expression of OV6 monoclonal antibody as cytoplasmic brownish color $(\uparrow)$ in hepatocytes like cells (*) and granuloma cells (Gr). E: Group IV (Untreated group) show few positive expressions of OV-6 ( $\uparrow)$ (IHC, DAB, x400). 


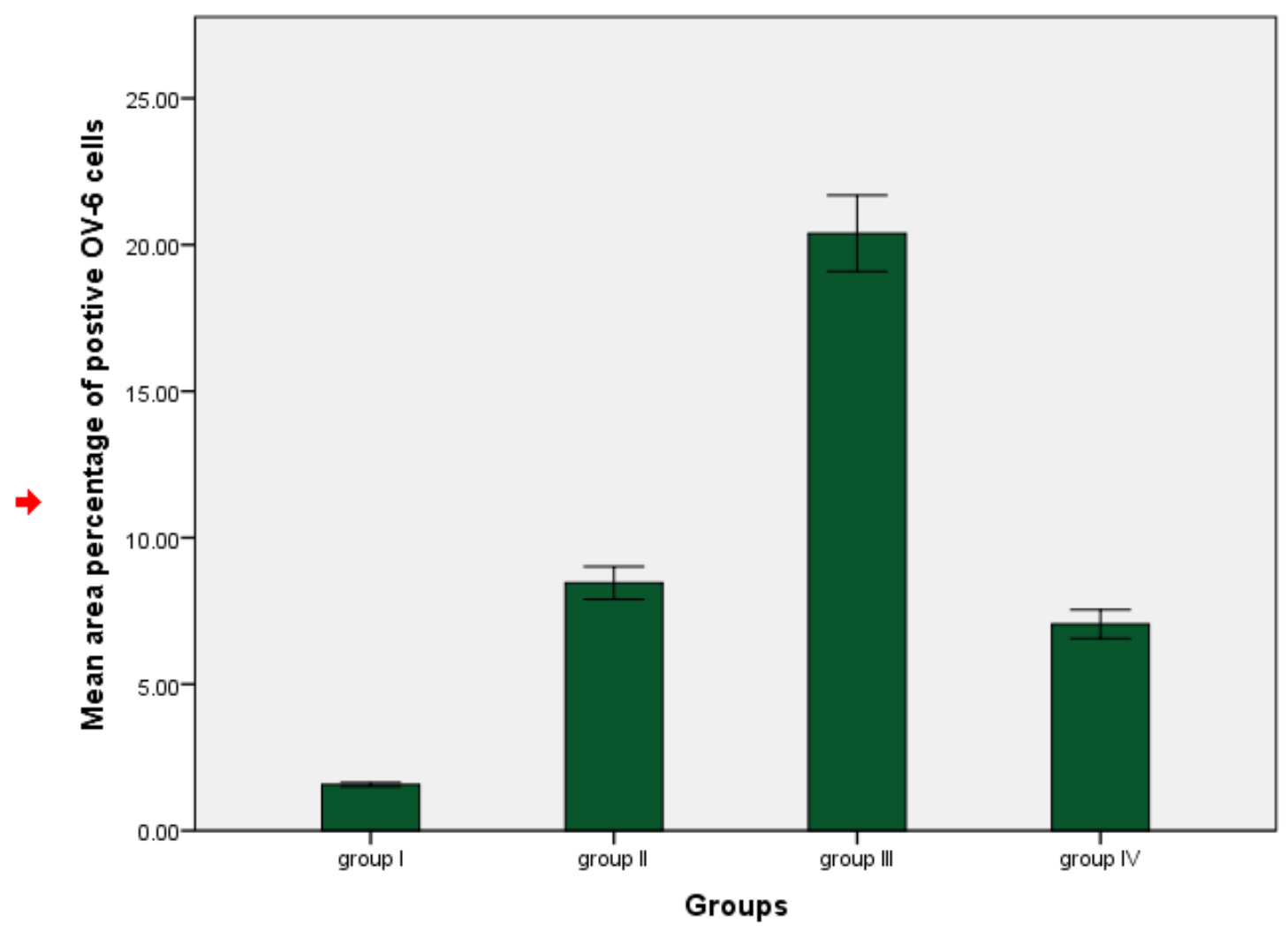

Fig. (13): The mean values of the area percentage of positive cells of OV-6 among the different study groups. 